\title{
Inhaled Drug Therapy 2016: The Year in Review
}

\author{
Rajiv Dhand MD FAARC
}

\author{
Introduction \\ Inhaled Tiotropium Therapy in Asthma \\ Small-Airway Disease in Asthma and Therapy With Small-Particle Aerosols \\ Inhaled Long-Acting Antimuscarinic Agent/Long-Acting $\beta$ Agonist \\ Therapy to Prevent Exacerbations in COPD \\ Inhalation Profile and Dry Powder Inhalers \\ Inhaled Gene Therapy in Cystic Fibrosis \\ Inhaled Antibiotic Therapy in Non-Cystic Fibrosis Bronchiectasis \\ Inhaled Interferon- $\gamma$ in Idiopathic Pulmonary Fibrosis \\ Food Flavoring in E-Cigarettes \\ Summary
}

\begin{abstract}
Some recent salient publications related to inhaled drug therapy are discussed. Unexpectedly, a $2.5-\mu \mathrm{g}$ once-daily dose of tiotropium (Respimat) had greater efficacy than the 5.0- $\mu \mathrm{g}$ daily dose. Occurrence of a reverse dose response serves to caution us that administering more drug is not always beneficial. Small-airway inflammation contributes to pathogenesis of asthma, especially severe asthma. However, there is no conclusive evidence that the use of small-particle aerosols to target small airways improves clinical outcomes in controlled clinical trials. Clinical outcomes of patients with symptomatic asthma have been better in "real-life" studies when fine-particle aerosols were compared with conventional (large-particle) aerosols. In subjects with COPD, the FLAME study indicates that a long-acting antimuscarinic agent/long-acting $\beta$-agonist combination was superior to an inhaled corticosteroid/longacting $\beta$-agonist combination in preventing exacerbations. Another study in children with asthma and adults with asthma or COPD showed that peak inhalation flow must be considered in the context of the dry powder inhaler resistance. Investigators from the United Kingdom have shown modest success in replacing the defective cystic fibrosis transmembrane regulator gene in subjects with cystic fibrosis with a plasmid encoding the normal cystic fibrosis transmembrane regulator gene packaged within a nonviral vector. Also, inhaled antibiotics in patients with non-cystic fibrosis bronchiectasis and inhaled interferon- $\gamma$ in patients with idiopathic pulmonary fibrosis have shown encouraging results but are investigational at this time. Compared to combustion cigarettes, use of e-cigarettes reduces exposure to carcinogens and volatile organic compounds. However, high levels of benzaldehyde in the vapor from cherry-flavored cigarettes raise concerns about the safety of some food flavorings in e-cigarettes. Key words: aerosols; asthma; COPD; dry powder inhalers; cystic fibrosis; bronchiectasis. [Respir Care 2017;62(7):978-996. (C) 2017 Daedalus Enterprises]
\end{abstract}

\section{Introduction}

Inhaled therapies have been employed for many centuries, but their increasing popularity in recent years could be attributed to the intuitive advantages of this route of administration over oral or parenteral administration. With aerosol therapy, drugs are delivered directly to their site of action in the lung for a localized effect, lower doses are needed, a rapid response is observed, and fewer adverse effects are observed compared with systemic administration of the same agents. These benefits of inhalation therapy are leading to increasing indications and usage in a variety of clinical settings. ${ }^{1}$ A PubMed search revealed $>1,200$ citations on aerosol therapy between January 2015 and September 2016. Some of the salient publications related to the use of aerosolized therapies in var- 
ious respiratory diseases, such as asthma, COPD, cystic fibrosis (CF), non-CF bronchiectasis, and idiopathic pulmonary fibrosis (IPF) are discussed in this review. Also included is a brief review of the possible harm in smoking flavored e-cigarettes.

\section{Inhaled Tiotropium Therapy in Asthma}

Inhaled drugs form the cornerstone of asthma treatment. The goals of asthma therapy, to minimize the frequency and severity of symptoms while optimizing pulmonary function with minimal drug-related adverse effects, can be ideally achieved with aerosol therapy. ${ }^{2} \mathrm{~A}$ broad range of $\beta$-adrenergic and anti-cholinergic bronchodilators, corticosteroids, and nonsteroidal anti-inflammatory agents are commonly employed as aerosols for treatment of asthma. The bronchodilator drugs include short-acting $\beta$ agonists, long-acting $\beta$-agonists (LABAs), short-acting antimuscarinic agents, long-acting antimuscarinic agents, combinations of bronchodilators (short-acting $\beta$ agonist + short-acting antimuscarinic agent, LABA + longacting antimuscarinic agent), or bronchodilators combined with inhaled corticosteroids (ICS). The use of inhaled LABA/ICS is one of the most popular options for patients whose asthma is not controlled with ICS alone. Despite treatment according to guidelines with ICS as monotherapy or in combination with LABAs, ${ }^{3}$ good control of asthma is not achieved in at least $40 \%$ of patients. ${ }^{4-6}$

Until recently, there were only a few therapeutic options for patients whose asthma is not controlled with secondline therapies. In such patients, one option is to add another controller therapy. ${ }^{3}$ Tiotropium, a long-acting antimuscarinic agent, and other anticholinergic drugs in inhalation formulations are cleared for use in patients with COPD, but until 2015, none of the anticholinergic drugs were cleared for treatment of asthma in the United States. In recent years, several investigations in subjects with symptomatic asthma of varying severity reported that the addition of tiotropium to standard ICS maintenance treatment, with or without a LABA, was safe and effective. ${ }^{7-15}$

Dr Dhand is affiliated with the Department of Medicine, University of Ten-

Dr Dhand discloses relationships with Bayer, AstraZeneca, Cipla (India), Mylan, and Sunovion.

Dr Dhand presented a version of this paper at the Year in Review of the AARC Congress 2016, held October 15-18, 2016, in San Antonio, Texas.

Correspondence: Rajiv Dhand MD FAARC, Department of Medicine, University of Tennessee Graduate School of Medicine, 1924 Alcoa Highway, U-114, Knoxville, TN 37920. E-mail: RDhand@utmck.edu.

DOI: $10.4187 /$ respcare. 05624
In subjects with mild or moderate asthma treated with ICS alone, the addition of tiotropium improved lung function and asthma control, 7,9,10,12,13,15 and the efficacy and safety of adding tiotropium to ICS in these subjects was comparable with a LABA (salmeterol) in combination with ICS.7, ${ }^{7,12}$ In subjects with more severe asthma, who were symptomatic despite receiving ICS doses of $\geq 800 \mu \mathrm{g}$ budesonide or equivalent plus a LABA, the addition of tiotropium improved lung function. ${ }^{8}$ The efficacy and safety of tiotropium was confirmed by 2 large, phase 3, 48-week randomized, double-blind, placebo-controlled studies with identical design. In these studies, the addition of tiotropium $(5 \mu \mathrm{g})$ not only provided sustained bronchodilation, ${ }^{11}$ but also reduced the risk of severe exacerbations and worsening asthma. ${ }^{11,14}$ Moreover, subgroup analyses of subjects in these studies found that tiotropium $(5 \mu \mathrm{g})$ as an add-on to ICS plus a LABA improved lung function, reduced the risk of exacerbations and asthma worsening, and improved asthma symptom control, independent of a broad range of their baseline characteristics. ${ }^{16}$

Tiotropium doses of 2.5 and $5.0 \mu \mathrm{g}$ daily were selected from 54 -8-week-long crossover design studies that employed inhaled doses of tiotropium ranging from 1.25 to $10 \mu \mathrm{g}$ once daily. ${ }^{17}$ Pivotal trials were conducted in $>3,000$ asthma subjects of varying severity (Table 1). These trials included some subjects with severe asthma who had a post-bronchodilator $\mathrm{FEV}_{1} / \mathrm{FVC}$ of $\leq 0.7$, signifying a degree of fixed airway obstruction that fulfilled spirometric criteria for COPD. ${ }^{18,19}$

These clinical trials demonstrated the superior efficacy of tiotropium delivery via the Respimat (BoehringerIngelheim, Ridgefield, Connecticut) in improving FEV $_{1}$ compared with placebo. It was also observed in 3 12-24week trials that the Respimat $2.5-\mu \mathrm{g}$ once-daily dose provided better overall improvement in $\mathrm{FEV}_{1}$ than the 5- $\mu \mathrm{g}$ dose (Table 1). The peak $\mathrm{FEV}_{1}(0-3 \mathrm{~h})$ and trough $\mathrm{FEV}_{1}$ responses were numerically higher for the $2.5-\mu \mathrm{g}$ dose compared with the 5- $\mu \mathrm{g}$ dose in the 3 trials that studied both doses, except for the trough $\mathrm{FEV}_{1}$ secondary end point in one trial. Compared with the 5- $\mu \mathrm{g}$ dose, the $2.5-\mu \mathrm{g}$ dose produced similar improvements in Asthma Control Questionnaire and Standardized Asthma Quality of Life Questionnaire scores, but the reduction in exacerbations was numerically superior. Moreover, the incidence of anticholinergic adverse reactions was low for both doses. In view of this evidence, in 2015, the FDA cleared the 2.5- $\mu \mathrm{g}$ dose of tiotropium bromide inhalation spray (Spiriva Respimat $1.25 \mu \mathrm{g} / \mathrm{dose}, 2$ inhalations/d) for the treatment of asthma in patients $\geq 12$ y old. ${ }^{17}$

Although tiotropium is available for inhalation via both the HandiHaler and Respimat devices, this dose for asthma is specific to Respimat and should not be extrapolated to the HandiHaler. In subjects with COPD, 6 clinical trials reported that the bronchodilator efficacy of tiotropium 
Table 1. Clinical Trials Comparing the Effects of Tiotropium (Spiriva Respimat) $2.5 \mu \mathrm{g}$ Versus $5 \mu \mathrm{g}$ Daily in Patients With Asthma

\begin{tabular}{|c|c|c|c|c|c|c|c|}
\hline Year & Subject Characteristics & Subjects $(N)$ & $\begin{array}{l}\text { Duration } \\
\text { (Weeks) }\end{array}$ & Treatment Groups & $\begin{array}{l}\Delta \mathrm{FEV}_{1} \\
(0-3 \mathrm{~h})\end{array}$ & $\begin{array}{c}\text { Mean Rate of Asthma } \\
\text { Exacerbation/Subject } \\
\text { Year }\end{array}$ & $\begin{array}{c}\text { Time to First } \\
\text { Exacerbation Hazard } \\
\text { Ratio }(95 \% \mathrm{CI})\end{array}$ \\
\hline \multirow[t]{3}{*}{2012} & \multirow{3}{*}{$\begin{array}{l}\text { Mild asthma, symptomatic on } \\
\text { low-dose ICS }\end{array}$} & 154 & 12 & Tio $(2.5 \mu \mathrm{g})$ & 0.293 & & \\
\hline & & 154 & & Tio $(5 \mu \mathrm{g})$ & 0.262 & & \\
\hline & & 155 & & Placebo & 0.134 & & \\
\hline \multirow[t]{4}{*}{2015} & \multirow{4}{*}{$\begin{array}{l}\text { Moderate asthma, symptomatic } \\
\text { on moderate-dose ICS }\end{array}$} & 269 & 24 & Placebo & 0.053 & 0.24 & \\
\hline & & 262 & & Tio $(2.5 \mu \mathrm{g})$ & 0.289 & 0.08 & $0.4(0.2-0.8)$ \\
\hline & & 264 & & Tio $(5 \mu \mathrm{g})$ & 0.250 & 0.19 & $0.7(0.4-1.4)$ \\
\hline & & 275 & & $\begin{array}{l}\text { Salmeterol }(50 \mu \mathrm{g}) \\
\quad \text { twice daily }\end{array}$ & 0.266 & & \\
\hline \multirow[t]{4}{*}{2015} & \multirow{4}{*}{$\begin{array}{l}\text { Moderate asthma, symptomatic } \\
\text { on moderate-dose ICS }\end{array}$} & 269 & 24 & Placebo & 0.075 & 0.18 & \\
\hline & & 257 & & Tio $(2.5 \mu \mathrm{g})$ & 0.287 & 0.13 & $0.7(0.3-1.3)$ \\
\hline & & 253 & & Tio $(5 \mu \mathrm{g})$ & 0.244 & 0.14 & $0.7(0.4-1.4)$ \\
\hline & & 266 & & $\begin{array}{l}\text { Salmeterol }(50 \mu \mathrm{g}) \\
\quad \text { twice daily }\end{array}$ & 0.252 & & \\
\hline $\begin{array}{l}\text { Data } \\
\text { ICS }= \\
\text { Tio }=\end{array}$ & $\begin{array}{l}\text { Reference } 17 . \\
\text { aled corticosteroids } \\
\text { ropium }\end{array}$ & & & & & & \\
\hline
\end{tabular}

HandiHaler $(18 \mu \mathrm{g})$ was similar to the efficacy of Respimat $5 \mu \mathrm{g}$ once daily. ${ }^{20}$ However, the bronchodilator efficacy of the 2.5- and 1.25- $\mu$ g doses with Respimat was lower than that with the HandiHaler. ${ }^{20}$

The therapeutic response to an inhaled drug is a function of the dose of the drug deposited at its site of action in the lung. ${ }^{21}$ Generally, the dose to the lung is influenced by factors operating in vitro (eg, device type and mass of particles $<5 \mu \mathrm{m}$ ) and those operating in vivo (eg, breathing pattern and nature of airway obstruction). Optimal therapeutic responses are obtained with aerosols in which the mass median aerodynamic diameter is between 0.5 and $5 \mu \mathrm{m} .{ }^{21}$ With pressurized metered-dose inhaler (pMDIs), $10-14 \%$ of the nominal dose is deposited in the lung. ${ }^{22}$ Thus, with a pMDI of ipratropium (nominal dose $36 \mu \mathrm{g}$ ), one would expect lung deposition of $\sim 4 \mu \mathrm{g}$. A similar lung deposition would be expected with the HandiHaler (nominal dose $18 \mu \mathrm{g}$ and efficiency of lung deposition of $\sim 20 \%$ ). In normal subjects, the efficiency of lung deposition with a Respimat has been reported to be as high as $50 \%$ of the nominal dose. ${ }^{23}$ With the tiotropium Respimat, it is estimated that $\sim 40 \%$ of the dose is deposited in the lung, so that with a nominal dose of $2.5 \mu \mathrm{g}$, only $\sim 1 \mu \mathrm{g}$ of the drug would be expected to deposit in the lung. This amount of drug deposition is significantly lower than that calculated with other delivery devices. Thus, a note of caution: The therapeutic dose of drugs cannot be determined solely by extrapolation between the delivery efficiencies of various aerosol delivery devices.

Another interesting aspect of these studies is the unique reverse dose response with lesser efficacy noted after administration of a 2-fold higher dose via Respimat. Previ- ous studies with different delivery devices found increasing response with bronchodilators in subjects with asthma or COPD. ${ }^{24-30}$ Typically, with higher doses in asthma trials, an efficacy plateau is attained with no incremental benefit but with increasing pharmacologic or toxic adverse effects. Corris et al, ${ }^{26}$ Jenkins et al, ${ }^{27}$ and Vathenen et $\mathrm{al}^{29}$ recommend a higher dose of albuterol in patients with COPD than the 2 puffs that are commonly employed. The optimal dose of albuterol from a pMDI in patients with COPD has been estimated to be between 4 and 8 puffs. ${ }^{27,31}$ Hitherto, the goal of inhalation therapy has been to attain a higher drug deposition in the lung so as to obtain therapeutic responses near the top of the dose-response curve. Although the mechanism for the apparent reverse dose response with the Respimat is not clear, it is conceivable that a small dose-related increase in anticholinergic adverse effects observed with the 5- $\mu$ g dose may have a long-term effect on bronchial secretions, resulting in less improvement in lung function and decreased benefit for other measures of asthma efficacy, such as exacerbations. These observations should caution us that more drug deposition in the lung does not always translate into greater benefits than smaller doses of the same drug.

Inhaled anticholinergics have been widely employed for management of COPD for many years, but Respimat is the first anticholinergic delivery device to be cleared for treatment of asthma. It is of great interest to note that lung deposition of a minute dose $(\sim 1 \mu \mathrm{g})$ of tiotropium produced consistent bronchodilator effects in patients with asthma, including some patients who had overlap features with COPD. In addition to the bronchodilator effects, Respimat, when administered as add-on therapy to an ICS, 
Table 2. Mass Median Aerodynamic Diameter of Aerosols Produced by Various Devices for Delivery of Inhaled Corticosteroids

\begin{tabular}{|c|c|c|c|}
\hline Inhaler Device & Drug Formulation & MMAD, $\mu \mathrm{m}$ (range) & First Author (Year) \\
\hline DPI (Diskus) & Fluticasone dipropionate & 5.4 & Martin $(2002)^{43}$ \\
\hline DPI (Turbuhaler) & Budesonide & 4.0 & Martin $(2002)^{43}$ \\
\hline DPI (Twisthaler) & Mometasone furoate & 3.7 & Yang $(2001)^{44}$ \\
\hline DPI (Ellipta) & Fluticasone furoate & $4.0(3.5-4.9)$ & Data on file, GSK* \\
\hline DPI (Diskus) & Fluticasone propionate and salmeterol & 3.5 & Lavorini $(2016)^{41}$ \\
\hline DPI (Ellipta) & Fluticasone furoate/vilanterol & $4.0(3.6-4.8) / 2.3(2.0-2.6)$ & Data on file, GSK* \\
\hline DPI (Nexthaler) & Beclomethasone dipropionate and formoterol & 1.5 & Nicolini $(2008)^{45}$ \\
\hline pMDI-HFA suspension & Fluticasone propionate and salmeterol & 2.7 & Leach $(2012)^{42}$ \\
\hline pMDI-HFA suspension & Fluticasone propionate & 2.4 & Cripps $(2000)^{46}$ \\
\hline pMDI-HFA solution & Beclomethasone dipropionate and formoterol & 1.5 & Acerbi $(2007)^{47}$ \\
\hline pMDI-HFA solution & Beclomethasone dipropionate & 1.1 & Leach $(1998)^{48}$ \\
\hline pMDI-HFA & Ciclesonide & 1.1 & Leach $(2006)^{49}$ \\
\hline \multicolumn{4}{|c|}{$\begin{array}{l}\text { Data from References } 40 \text { and } 41 . \\
\text { * GlaxoSmithKline, Philadelphia, Pennsylvania. } \\
\text { MMAD = mass median aerodynamic diameter } \\
\text { DPI = dry powder inhaler } \\
\text { pMDI = pressurized metered-dose inhaler } \\
\text { HFA = hydrofluoroalkane }\end{array}$} \\
\hline
\end{tabular}

demonstrated improvement in asthma exacerbation and in the Asthma Control Questionnaire and Standardized Asthma Quality of Life Questionnaire. Furthermore, use of tiotropium is not associated with some of the major safety concerns surrounding LABAs, such as asthma-related deaths and serious asthma exacerbations. Thus, clinicians may consider using Respimat as an alternative longacting bronchodilator or as an additional therapy in patients who remain symptomatic despite therapy with a high-dose ICS/LABA combination. ${ }^{32}$

\section{Small-Airway Disease in Asthma and Therapy With Small-Particle Aerosols}

As mentioned earlier in this review, therapeutic options for patients with asthma who do not gain good control with a combination of ICS/LABA are limited. Regular treatment with the ICS/LABA combination (fluticasone propionate and salmeterol) for $1 \mathrm{y}$ achieved total control of asthma in less than half of subjects, and only about two thirds were well controlled. ${ }^{4}$ These results could not be attributed to a lack of subject adherence with medication. In fact, lower levels of asthma control were observed in subjects with milder disease receiving low-dose ICS/LABA than in those receiving ICS monotherapy. ${ }^{4}$ Furthermore, a post hoc analysis of the Formoterol and Corticosteroid Establishing Therapy (FACET) study 33,34 found that only about two thirds of subjects with asthma treated with high-dose combination ICS/LABA (budesonide [800 $\mu \mathrm{g}$ ]/formoterol [24 $\mu \mathrm{g}$ ] daily) for $1 \mathrm{y}$ achieved good control during the last 2 months of the study.

In asthma, small airways, defined as airways with an internal diameter $<2 \mathrm{~mm}$ (comprising airway generations
$8-23$ ), are believed to contribute to air-flow limitation ${ }^{35,36}$ in patients with mild asthma, ${ }^{37,38}$ and they are especially important in the pathogenesis of air-flow limitation in patients with severe asthma. ${ }^{36,39}$ Hence, enhancing deposition of ICS in the small airways could lead to better control of inflammation in these airways. ${ }^{40,41}$

The importance of small-airway involvement in asthma pathogenesis suggests that achieving higher deposition of ICS in these airways with the use of small particle aerosols $(<2 \mu \mathrm{m}$ in size) may improve asthma control in patients who are not adequately controlled with conventional ICS/LABA combination therapy. ${ }^{41,42}$ Aerosol delivery devices produce aerosols of different aerodynamic diameters (Table 2). Aerosols with mass median aerodynamic diameter $\leq 2.0 \mu \mathrm{m}$ show greater peripheral deposition in the lung compared with aerosols with a larger mass median aerodynamic diameter. ${ }^{42,48,49}$ In subjects with mild asthma, Usmani and colleagues ${ }^{50,51}$ demonstrated that small (1.5$\mu \mathrm{m})$ particles of an albuterol formulation achieved greater lung deposition than larger 3- and 6- $\mu \mathrm{m}$ particles. Lung deposition studies in subjects with mild asthma that reported 56 and $42 \%$ peripheral lung deposition as a proportion of total lung dose with pMDI hydrofluoroalkane (HFA)-solution ciclesonide $(\sim 1.1 \mu \mathrm{m})^{49,52}$ and beclomethasone dipropionate $(\sim 0.9 \mu \mathrm{m})^{42}$ support the use of small-particle aerosols for targeted delivery of ICS to small airways.

Improvement in markers of small-airway dysfunction and inflammation in both asthma and COPD have been reported by several investigators with small-particle aerosols. ${ }^{53,54}$ Do small-particle aerosols lead to added clinical benefit in patients with asthma when compared with largeparticle aerosols? Only a few investigators have compared 
the effect of the same drug delivered as a small- or a large-particle aerosol. A review of controlled clinical trials comparing chlorofluorocarbon- with HFA-beclomethasone dipropionate concluded that the use of small-particle aerosols did not provide additional clinical benefits compared with large particle aerosols..$^{40}$ However, real-life studies in both adults and children, especially in younger children, have shown improvement in daily asthma control, quality of life, and reduction in ICS dose with small-particle aerosols. ${ }^{55-63}$ Greater lung deposition with small-particle aerosols has not been associated with an increase in associated systemic adverse effects. ${ }^{64}$ Thus, greater and more peripheral drug deposition in the small airways occurs when small-particle aerosols are employed, and there is improvement in markers of small-airway inflammation. However, further clinical studies are needed to demonstrate that use of such ICS formulations improves control across a spectrum of severity of asthma patients, especially in those patients who are not well controlled despite the use of high-dose conventional ICS/LABA combination therapy.

\section{Inhaled Long-Acting Antimuscarinic Agent/LABA Therapy to Prevent Exacerbations in COPD}

COPD is a preventable and treatable disease that presents an increasing major public health challenge all over the world. According to the National Health and Nutrition Examination Survey IV, an estimated 15.7 million persons have been diagnosed with COPD in the United States. ${ }^{65}$ However, it is believed that many more persons, perhaps an equal number, have the disease but have not been diagnosed. ${ }^{66}$ Worldwide, $>200$ million persons are estimated to be suffering from COPD. ${ }^{67}$

Inhaled bronchodilators form the cornerstone of therapy for COPD. Both parasympathetic and sympathetic nervous systems are involved in the control of airway tone. Relaxation of smooth muscle in the airway occurs after blockage of the muscarinic receptors by anticholinergic agents or stimulation of the $\beta$-adrenergic receptor with a $\beta$-agonist. The combination of anticholinergic drugs and $\beta_{2}$-agonist bronchodilators have several advantages in terms of efficacy, convenience, and safety compared with the individual agents, and a combination of long-acting bronchodilators (long-acting antimuscarinic agent/LABA) is recommended for patients in whom a single bronchodilator is unable to control symptoms.

The course of COPD is characterized by exacerbations, episodes of acute worsening of symptoms that require additional therapy. Exacerbations result in significant morbidity and mortality, and prevention of exacerbations is a key goal in the management of COPD. ${ }^{19}$ Inhaled longacting bronchodilators improve symptoms in patients with COPD and also reduce the frequency of exacerbations. ${ }^{68-71}$ Inhaled glucocorticoids also prevent exacerba- tions, and they are employed in combination with inhaled LABAs. ${ }^{70,72,73}$ Treatment guidelines recommend the use of either an ICS/LABA combination or a long-acting antimuscarinic agent to prevent COPD exacerbations in highrisk patients ${ }^{19}$ based on a trial comparing the effects of a combination of salmeterol-fluticasone in fixed doses with tiotropium. ${ }^{74}$ However, long-term use of ICS in patients with COPD is associated with adverse effects, ${ }^{75}$ including a higher risk of pneumonia. ${ }^{76,77}$ Several investigators have reported that the combination of glycopyrronium and indacaterol is effective and safe in patients with $\mathrm{COPD}^{78-90}$ (Table 3). A long-acting antimuscarinic agent/LABA regimen, such as glycopyrronium-indacaterol, may be a more attractive option to prevent exacerbations in high-risk patients as an alternative to an ICS/LABA combination. ${ }^{88}$

The FLAME study ${ }^{90}$ was a multi-center, randomized, double-blind, double-dummy, parallel-group, non-inferiority trial. Subjects were randomly assigned (1:1 ratio) to receive either glycopyrronium $(50 \mu \mathrm{g})$ plus indacaterol $(110 \mu \mathrm{g})$ once daily or salmeterol (50 $\mu \mathrm{g})$ plus fluticasone $(500 \mu \mathrm{g})$ twice daily for 52 weeks, with an additional $30 \mathrm{~d}$ of follow-up after discontinuation of the study regimen. Subjects enrolled in this study were $\geq 40 \mathrm{y}$ old and had symptoms of COPD, post-bronchodilator $\mathrm{FEV}_{1} \quad 25-60 \%$ of the predicted value, post-bronchodilator $\mathrm{FEV}_{1} / \mathrm{FVC}<0.70$, and a documented history of at least one COPD exacerbation during the previous year for which they received treatment with systemic glucocorticoids, antibiotic agents, or both..$^{90}$ Such a history of recent exacerbations is an important indicator of future exacerbation risk. ${ }^{92}$

The primary objective of the FLAME trial ${ }^{90}$ was to show that glycopyrronium-indacaterol was not inferior to salmeterol-fluticasone in reducing the annual rate of all COPD exacerbations (mild, moderate, or severe). If this objective was met, an important secondary objective was to determine whether glycopyrronium-indacaterol was superior to salmeterol-fluticasone in reducing the annual rate of all COPD exacerbations. The investigators found that in the per-protocol population, the annual rate of all COPD exacerbations was $11 \%$ lower in the glycopyrroniumindacaterol group compared with the salmeterol-fluticasone group $(P=.003)$. Glycopyrronium-indacaterol was not inferior to salmeterol-fluticasone with regard to the annual rate of all COPD exacerbations in the per-protocol and modified intention-to-treat population. In a secondary analysis, glycopyrronium-indacaterol showed superiority to salmeterol-fluticasone in reducing the annual rate of all COPD exacerbations in both per-protocol and modified intentionto-treat populations (Table 4).

When compared with the salmeterol-fluticasone group, glycopyrronium-indacaterol was associated with reduced risks of $16 \%$ for all exacerbations $(P<.001), 22 \%$ for moderate-to-severe exacerbations $(P<.001)$, and $19 \%$ for severe exacerbations $(P=.046)$. The incidence of adverse 


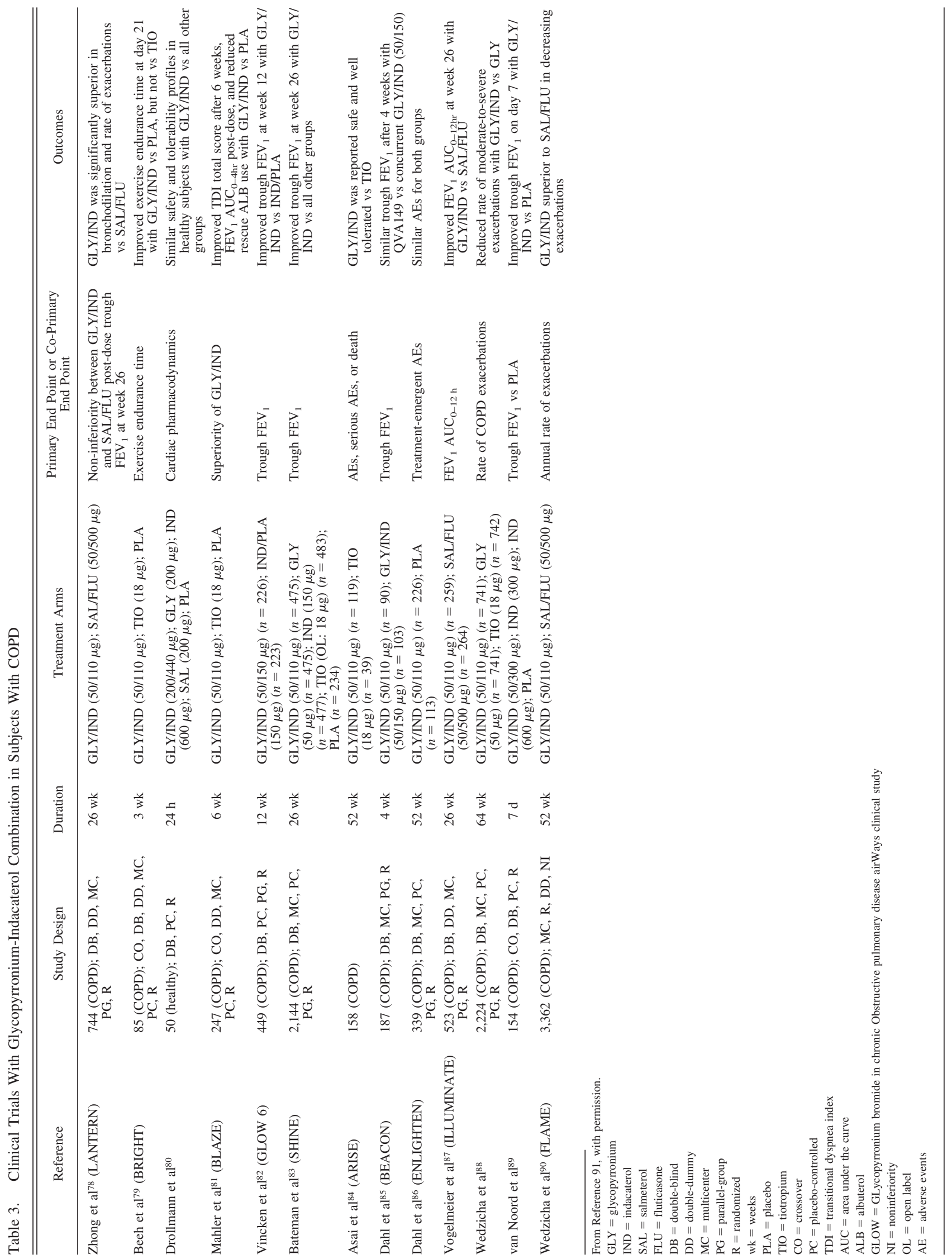


Table 4. Subject Characteristics and Effects of Glycopyrronium-Indacaterol Versus Salmeterol-Fluticasone in the FLAME Trial

\begin{tabular}{|c|c|c|c|}
\hline Parameter & $\begin{array}{l}\text { Glycopyrronium-Indacaterol } \\
\qquad(n=1,680)\end{array}$ & $\begin{array}{l}\text { Salmeterol-Fluticasone } \\
\quad(n=1,682)\end{array}$ & $P$ \\
\hline Age, mean $\pm \mathrm{SD}$ y & $64.6 \pm 7.9$ & $64.5 \pm 7.7$ & NS \\
\hline Duration of COPD, mean $\pm \mathrm{SD} y$ & $7.5 \pm 5.3$ & $7.3 \pm 5.5$ & NS \\
\hline Current smoker, $n(\%)$ & $664(39.5)$ & $669(39.8)$ & NS \\
\hline Post-bronchodilator $\mathrm{FEV}_{1}$, mean $\pm \mathrm{SD} \mathrm{L}$ & $1.2 \pm 0.3$ & $1.2 \pm 0.4$ & NS \\
\hline Post bronchodilator $\mathrm{FEV}_{1}$, mean $\pm \mathrm{SD} \%$ predicted & $44.0 \pm 9.5$ & $44.1 \pm 9.4$ & NS \\
\hline Post bronchodilator $\mathrm{FEV}_{1} / \mathrm{FVC}$, mean $\pm \mathrm{SD}$ y & $41.7 \pm 9.8$ & $41.5 \pm 9.9$ & NS \\
\hline Time to first exacerbation, median $(95 \% \mathrm{CI}) \mathrm{d}$ & $71(60-82)$ & $51(46-57)$ & $<.001 *$ \\
\hline Annual rate of moderate or severe exacerbations, median ( $95 \% \mathrm{CI})$ & $0.98(0.88-1.10)$ & $1.19(1.07-1.32)$ & $<.001$ \\
\hline Time to first moderate or severe exacerbation, median $(95 \% \mathrm{CI}) \mathrm{d}$ & $127(107-149)$ & $87(81-103)$ & $<.001 \dagger$ \\
\hline $\begin{array}{l}\text { Data from Reference } 90 . \\
* \text { Hazard ratio } 0.84 . \\
\dagger \text { Hazard ratio } 0.78 \text {. } \\
\text { NS = not significant }\end{array}$ & & & \\
\hline
\end{tabular}

Table 5. Fixed-Dose Long-Acting Antimuscarinic Agent/Long-Acting $\beta$-Agonist Combinations

\begin{tabular}{llll}
\hline \hline \multicolumn{1}{c}{ Drug } & \multicolumn{1}{c}{ Trade Name } & \multicolumn{1}{c}{ Device } & \multicolumn{1}{c}{ Approved Dose } \\
\hline Umeclidinium/vilanterol & Anoro & Ellipta DPI & $62.5 / 25 \mu \mathrm{g}$ once daily \\
QVA 149 & Bltibro & Breezhaler DPI & $85 / 43 \mu \mathrm{g}$ once daily (Europe) \\
Glycopyrronium/indacaterol & Brimica & Genuair DPI & $27.5 / 12.5 \mu \mathrm{g}$ twice daily (United States) \\
Aclidinium/formoterol & Stiolto & Respimat SMI & $340 / 12 \mu \mathrm{g}$ twice daily \\
Tiotropium/olodaterol & Bevespi Aerosphere & pMDI & $2.5 / 2.5 \mu \mathrm{g} 2$ puffs once daily \\
Glycopyrrolate/formoterol & & & $9 / 4.8 \mu \mathrm{g} 2$ puffs twice daily \\
DPI = dry powder inhaler & & & \\
SMI $=$ soft mist inhaler & & & \\
pMDI = pressurized metered-dose inhaler & & & \\
\hline
\end{tabular}

events or death in the glycopyrronium-indacaterol group was similar, and the rate of pneumonia was lower compared with the salmeterol-fluticasone group. Likewise, analysis of pooled data in $>11,000$ subjects has shown a favorable adverse effect profile for glycopyrronium-indacaterol with no significant increase in the overall risk of death, major cardiovascular events, or pneumonia compared with placebo. ${ }^{93}$

The once-daily dose of glycopyrronium-indacaterol is approved worldwide, except in the United States, where a lower, twice-daily dose of glycopyrronium-indacaterol is approved (Table 5). Clinical trials have shown that the twice-daily regimen has effects on lung function that are similar to those observed with a once-daily dosing regimen, but no direct comparison has been performed. ${ }^{83,94}$ Other combinations of long-acting antimuscarinic agent and LABA are approved in the United States (see Table 5). The mechanism(s) by which long-acting antimuscarinic agent/LABA combinations reduce exacerbations are not clear, but several potential explanations have been proposed, including the effects on diminishing hyperinflation and mechanical stress, decreasing excessive mucus pro- duction and impaired mucociliary clearance, and reducing inflammation and symptom severity. ${ }^{95}$ The widespread availability of these fixed-dose once-daily long-acting antimuscarinic agent/LABA combinations means that they are likely to be employed more frequently as alternatives to ICS and LABA combinations for prevention of exacerbations in patients with COPD who are at higher risk of developing exacerbations.

\section{Inhalation Profile and DPIs}

In most DPIs, the formulation is a blend of larger-size carrier particles, generally lactose, and smaller drug crystals of $\sim 2 \mu \mathrm{m}$ in size. ${ }^{96}$ DPIs are breath-actuated so that, unlike pMDIs, coordination between inhalation and actuation is not required. The ability to produce an aerosol that contains the majority of drug particles in the $1-5-\mu \mathrm{m}$ size range that is optimal for deposition in the respiratory tract depends on inspiratory air flow. ${ }^{96,97}$ In DPIs that contain drug particles blended with carrier lactose particles, turbulent energy created in the inhalation channel of the DPI by the interaction of inspiratory air flow with the resis- 
Table 6. Resistance of Various Dry Powder Inhalers

\begin{tabular}{|c|c|c|c|c|}
\hline DPI Brand & Type of DPI & Resistance Level & Resistance, $(\mathrm{kPa})^{0.5}(\mathrm{~L} / \mathrm{min})^{-1}$ & Resistance, $\left(\mathrm{cm} \mathrm{H}_{2} \mathrm{O}\right)^{1 / 2}(\mathrm{~L} / \mathrm{min})^{-1}$ \\
\hline Aerolizer & Capsule & Low & 0.0207 & 0.066 \\
\hline Diskus & Individual blisters & Medium & 0.0249 & 0.079 \\
\hline Ellipta & Individual blisters & Medium & $0.0286^{*}$ & $0.091 *$ \\
\hline Turbuhaler & Multi-dose reservoir & Medium/High & 0.0335 & 0.110 \\
\hline Twisthaler & Multi-dose reservoir & High & 0.0432 & 0.138 \\
\hline HandiHaler & Capsule & High & 0.0494 & 0.158 \\
\hline \multicolumn{5}{|c|}{$\begin{array}{l}1 \mathrm{kPa}=10.1972 \mathrm{~cm} \mathrm{H}_{2} \mathrm{O} . \\
\text { * For the 2-strip configuration. }{ }^{100} \\
\mathrm{DPI}=\text { dry powder inhaler }\end{array}$} \\
\hline
\end{tabular}

tance of the DPI dissociates the drug particles from the carrier particles. This turbulent energy produces a pressure change that breaks up (de-aggregates) the formulation and entrains the de-aggregated drug particles in the inspiratory air flow. ${ }^{98}$ The magnitude of the pressure change depends on the strength of the respiratory muscles, the degree of patient effort (ie, the force of the inhalation), and, to a much lesser extent, on disease severity. ${ }^{99}$

DPIs have different resistances (Table 6); thus, variable levels of inspiratory force are needed to ensure efficient de-aggregation of the drug particles from the larger carrier particles. The faster the inhalation flow through a DPI, the greater the resultant energy and more efficient is the break-up of the formulation. ${ }^{101}$ Although the degree of powder de-agglomeration increases with increasing inspiratory flow, the higher flows are also associated with greater impaction as a result of the increased particle velocity. The net effect of these opposing forces on lung deposition of the drug could be positive, neutral, or negative, depending on the design of the device and the formulation. ${ }^{102}$ Moreover, focusing on the peak inhalation flow alone, without integrating device resistance, device design, and formulation, leads to the misconception that low flows through some DPIs with higher resistance leads to inadequate dose delivery.

All DPIs demonstrate flow-dependent dose emission, with some DPIs being more prone to this phenomenon than others. ${ }^{101,102}$ The turbulent energy inside a DPI during an inhalation is the product of the inhalation flow and the device resistance according to the formula, $\sqrt{ } \mathrm{P}=\mathrm{Q} \times \mathrm{R}$, where $\mathrm{P}$ is the turbulent energy, $\mathrm{Q}$ is the inhalation flow, and $\mathrm{R}$ is the resistance of the device. Thus, for devices with a higher resistance, a lower flow will be required to achieve a given energy level compared with a device with a lower resistance. Therefore, a low flow through a DPI with a high resistance generates the same turbulent energy as fast flow through a device with low resistance. Depending on the device, different inhalation flows are compatible with effective use, and there is no defined peak inhalation flow that is optimal for all DPIs. In fact, DPIs with a higher resistance tend to provide greater lung deposition with less variability in the delivered dose compared with DPIs with a lower resistance. ${ }^{103,104}$

For each DPI, a minimum turbulent energy must be achieved for sufficient de-aggregation during an inhalation. ${ }^{105}$ The minimum acceptable peak inhalation flow achieved through each DPI, rather than the optimal flow, is critical for adequate de-aggregation. Inability to achieve this minimum flow will result in inefficient de-aggregation. However, the threshold flow will differ for various DPIs, depending on their resistance. For DPIs with a higher resistance, the peak inhalation flow needed to achieve a critical threshold for energy generation will be lower than that required for a DPI with a lower resistance. For the Turbuhaler and the Diskus, the minimum effective flow has been regarded as $30 \mathrm{~L} / \mathrm{min} .{ }^{106,107}$ Both in vitro and in vivo studies have shown that unless this minimum flow is achieved, the turbulent energy generated is not sufficient to achieve adequate de-aggregation of the powder, and this inability to achieve an adequate inspiratory flow could influence the clinical response to the drug. ${ }^{106,108}$

The peak inhalation flow achieved by patients through each DPI is related to clinical efficacy 106,107,109,110; however, the pressure changes inside the inhalation channel of each DPI ${ }^{111}$ and the initial acceleration rate of the inhalation maneuver ${ }^{112,113}$ may be more important than peak inhalation flow in the generation of the fine-particle dose. Moreover, inhaled volume is another factor that influences the quality of the emitted dose, ${ }^{113}$ particularly in a capsule formulation ${ }^{114,115}$ because of the need to empty the capsule. For optimal use of DPIs, it is recommended to seal the lips around the device and employ a forceful and deep inhalation that begins from the start of the inhalation maneuver so as to provide adequate de-aggregation, dispersion of the drug particles into the airstream, emptying of the dose from the device, and adequate air flow needed for drug deposition in the lung. ${ }^{96,111}$

Some patients may have problems achieving a fast inhalation rate, and they may be unable to achieve adequate inspiratory flows for optimal aerosol generation with a 

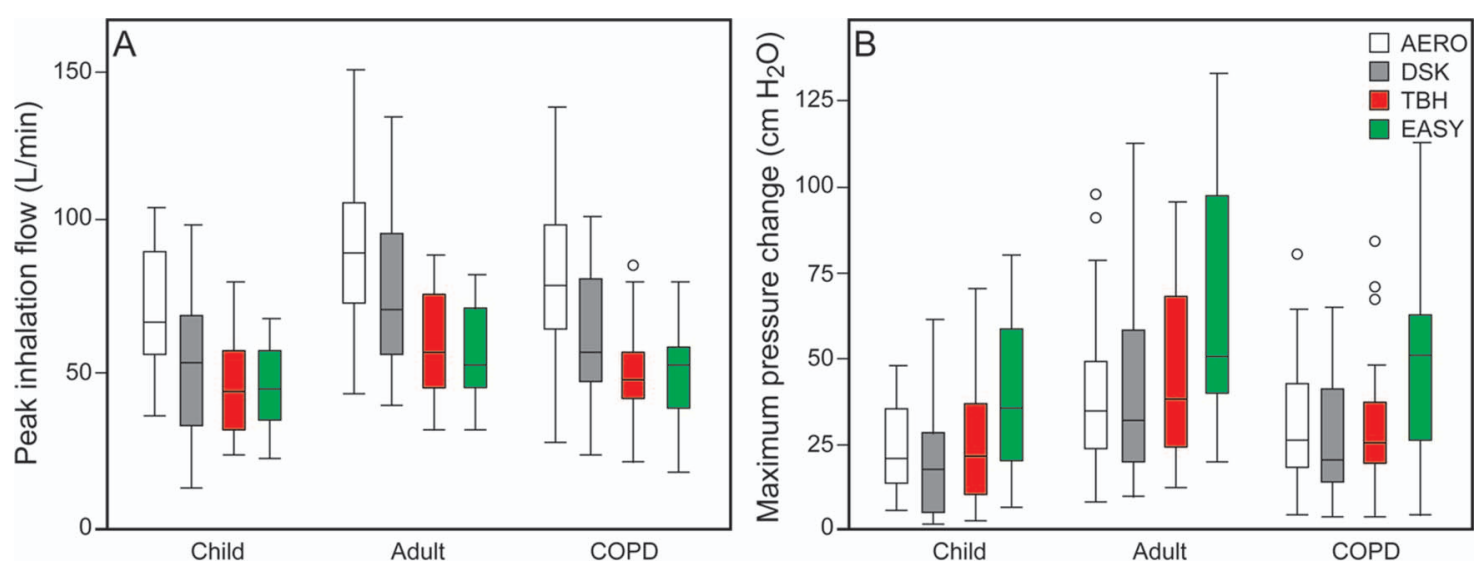

Fig. 1. A: Distribution of peak inhalation flows of inhalation maneuvers through various DPIs. As expected, adults with asthma generate the most favorable inhalation maneuver and children with asthma the weakest, and COPD subjects performed slightly better than the children. Also, as expected, subjects generated higher flows through lower resistance devices (AERO, DSK) as compared to higher resistance devices (TBH, EASY). B: Distribution of pressure change during each inhalation maneuver through each DPI. In contrast to the peak inhalation flows (A), the pressure changes tended to be greater for DPIs with a higher resistance (TBH, EASY) than those with a lower resistance (AERO, DSK). Boxes represent interquartile range with the median, and whiskers show the full range of the data, with outliers are shown as circles. AERO $=$ Aerolizer, DSK $=$ Diskus, TBH $=$ Turbuhaler, EASY $=$ Easyhaler. From Reference 117 , with permission.

DPI. Azouz et al ${ }^{116}$ measured the inhalation profiles of subjects when they inhaled through 4 different DPIs in an open-label study. Children with asthma (age 5-17 y), adults with asthma (age 18-55 y), and COPD subjects $>55 \mathrm{y}$ of age inhaled through DPIs as they would normally do at home.

Empty, placebo versions of 4 DPIs, the Aerolizer (Novartis, Basel, Switzerland), Diskus (GlaxoSmithKline, Brentford, United Kingdom), Easyhaler (Orion, Espoo, Finland), and the Turbuhaler (Symbicort version, AstraZeneca, Södertälje, Sweden), were employed in random order. The placebo version of the Diskus containing the foil strips from which the lactose had been discharged was used. The Aerolizer contained a pierced empty capsule for each inhalation, because the device resistance is lower without it.

Flows were converted into pressure changes using the resistance of the DPI. The inhalation characteristics obtained from each inhalation profile were the peak inhalation flow (in $\mathrm{L} / \mathrm{min}$ ), the time after start of the inhalation when peak inhalation flow occurred (in s), the maximum pressure change that occurred inside the DPI (in $\mathrm{cm}_{2} \mathrm{O}$ ), the initial acceleration of the inhalation flow (in $\mathrm{cm} \mathrm{H}_{2} \mathrm{O} / \mathrm{s}$ ), the inhalation volume (in L), and the duration of the inhalation (in s) (Fig. 1).

The investigators found a large variability in inhalation characteristics of subjects. Peak inhalation flow, DPI pressure, and initial inhalation acceleration values were consistent with the order of the inhaler's resistance. For each device, the inhalation characteristics were in the order adults $>$ COPD subjects $>$ children for peak inhalation flow, pressure change inside the DPI, and initial inhalation acceleration $(P<.001)$. Measurement of DPI pressure and inhalation acceleration had an advantage over peak inhalation flow values. Overall inhaled volumes were low, and only one subject achieved an inhaled volume $>4 \mathrm{~L}$ and pressure change inside the DPI $>40.79 \mathrm{~cm} \mathrm{H}_{2} \mathrm{O} .{ }^{116}$ The inhalation characteristics highlight that adults with asthma have greater inspiratory capacity than patients with COPD, whereas children with asthma have the lowest. Combining measurement of inhalation profiles with in vitro dose emission measurements could provide useful information about the dose that patients inhale during routine use from various DPIs.

In summary, there has been a great deal of focus on achieving a high peak inhalation flow when using a DPI. The inhalation flow needs to be integrated with the resistance of the DPI and to the turbulent energy achieved within the inhalation channel to better compare the performance of various devices, because higher resistance devices require lower flows to achieve the same energy level compared with lower-resistance devices. It also needs to be stressed that, more than the high peak inhalation flow, it is the minimum peak inhalation flow that is of critical importance for optimal aerosol generation from a DPI. The minimum flow, below which efficient de-aggregation of the powder will not occur, also differs for various DPIs, depending on their resistance. Furthermore, Azouz et al ${ }^{116}$ emphasize that in addition to the flow-dependent pressure changes achieved within the inhalation channel, patients need to be trained to appropriately accelerate their inhalation maneuver and achieve an adequate inhalation volume to optimize DPI performance. 


\section{Inhaled Gene Therapy in CF}

Cystic fibrosis is a chronic, life-limiting disease caused by mutations in the $\mathrm{CF}$ transmembrane conductance regulator (CFTR) gene encoding a chloride ion channel that is active on the apical surfaces of epithelia. CF is a multisystem disease, primarily affecting the lungs but also involving the pancreas, liver, and gastrointestinal tract, and is associated with infertility in the majority of males. Lung involvement occurs from an early age, with intermittent and then chronic bacterial infection, inflammation, and eventual bronchiectasis, fibrosis, and death from respiratory failure. ${ }^{118,119}$ The gene responsible for CF is localized to the long arm of chromosome 7, position 7q21-24. ${ }^{120,121}$ The CFTR gene encodes a 1,480-amino-acid CFTR protein $^{122}$ that when fully processed localizes to the plasma membrane in normal epithelial cells and acts as a cyclic adenosine monophosphate-regulated ion channel. CFTR is a direct conductor of chloride ions, and it also inhibits the major sodium-absorbing channel, the epithelial sodium channel. Defects in CFTR lead to reduced chloride secretion, and loss of inhibition of the epithelial sodium channel leads to increased absorption of sodium. Water absorption is also increased along with sodium, and this leads to dehydration of the cell surface ${ }^{123}$ and acidification of the airway surface liquid. ${ }^{124}$ In addition, increased mucin polymer cross-links make the mucus more viscous, and in the presence of a larger amount of mucus, mucociliary clearance is impaired. ${ }^{125}$ The inspissated mucus obstructs airways, leading to pulmonary infections and inflammation. ${ }^{126}$ Massive infiltration of inflammatory cells into the airways in CF causes tissue damage due to the secretion of excessive amounts of elastase and other proteinases. ${ }^{127}$ The release of proteolytic enzymes, such as elastase, causes lung damage and leads to bronchiectasis and impaired lung function. Furthermore, DNA released from dead neutrophils also contributes to the increased viscosity of CF sputum. ${ }^{128}$ Ultimately irreversible airway scarring, bronchiectasis, and respiratory failure ensue. A few decades ago, a patient with $\mathrm{CF}$ was not expected to reach adulthood, but intensive efforts, new and more effective treatments, and improvements in early diagnosis, nutritional support, and clinical care have dramatically increased the survival rates. The median predicted survival age for a child born with $\mathrm{CF}$ in the United States is currently $\sim 40$ y. ${ }^{129}$

Ivacaftor (Kalydeco, Vertex Pharmaceuticals, Boston, Massachusetts) is the only licensed therapy targeting the basic defect in $\mathrm{CF}, 130$ but it is currently suitable for only a minority of patients $(4-5 \%)$ with a relatively rare CFTR gene mutation. All of the other clinically available treatments target the consequences of the disease and at best delay the decline in lung function.

Gene therapy has enormous potential to treat CF. Investigations to replace the defective CFTR gene in the airway epithelial cells with a normal copy of the CFTR gene have been ongoing for many years. Several vectors have been studied for gene transfer. Initially, viral vectors were employed, but they have the potential to produce inflammatory and immune reactions in the lung. ${ }^{131,132}$ Nonviral vectors, which are generally complexes of plasmid DNA with liposomes, have the ability to deliver larger amounts of genetic material than viral vectors, can be produced on a large scale with high reproducibility and acceptable costs, and are relatively stable for storage purposes. Non-viral vectors can also be administered repeatedly with minimal immune response. ${ }^{133}$ Most non-viral vectors comprise cationic lipids and polymers, as well as peptides, which form compacted DNA nanoparticles. ${ }^{134}$ These vectors form condensed complexes with negatively charged DNA through electrostatic interactions, which protect nucleic acids from enzymatic degradation and facilitate their uptake within cells. ${ }^{135}$ A cationic lipid named GL67A38, which was designed to facilitate the endosomal escape of plasmid DNA and to be stable for aerosol administration, is currently one of the leading non-viral vectors for CF gene therapy. ${ }^{136}$

Alton et al ${ }^{137}$ conducted a randomized, double-blind, placebo-controlled, phase $2 \mathrm{~b}$ trial to assess the clinical efficacy of inhaled non-viral CFTR gene-liposome complex (pGM169/GL67A) in 136 subjects with CF who were at least $12 \mathrm{y}$ old and had mild-to-moderate lung disease, with $\mathrm{FEV}_{1}$ between 50 and $90 \%$ of predicted. The non-viral formulation comprised a plasmid, pGM169, encoding the CFTR gene driven by a CpG-free human cytomegalovirus enhancer/elongation factor 1a (hCEFI) enhancer/promoter. pGM169 is a covalently closed, circular, double-stranded plasmid DNA molecule of 6,549 base pairs purified from bacteria. The cationic lipid (GL67A) is made up of 3 components to optimize DNA binding, stability, and gene transfer. The formulation was nebulized via a breath-actuated nebulizer, the AeroEclipse II (Trudell Medical International Europe, Nottingham, United Kingdom). Subjects received $5 \mathrm{~mL}$ of pGM169/lipid 67A (GL67A) (active) or $0.9 \%$ saline (placebo) at $28 \pm 5-\mathrm{d}$ intervals over $1 \mathrm{y}$. The primary end point was the relative change in percent-of-predicted $\mathrm{FEV}_{1}$ over the 12-month period.

The per-protocol cohort was predefined as those subjects who received at least 9 monthly doses of the trial formulation; it consisted of 62 subjects who received gene therapy and 54 who received placebo. The primary end point of relative change in percent-of-predicted $\mathrm{FEV}_{1}$ at 12 months showed a significant $(P=.046)$ treatment effect of $3.7 \%$ (95\% CI $0.1-7.3 \%) .137$ The responses were noted as soon as 1 month after administration and were irrespective of sex, age, or CFTR mutation class. There were also significant improvements in FVC and gas trapping on CT scans. The formulation was safe and did not 
lead to the generation of host immune responses. Although the results are encouraging, the difference in $\mathrm{FEV}_{1}$ between groups was modest and was not accompanied by detectable improvement in the quality of life of the subjects. The development of a suitable non-viral vector that could transfect epithelial cells after inhalation is significant for gene therapy in $\mathrm{CF}$ and provides hope that gene therapy strategies for $\mathrm{CF}$ based on non-viral vectors will be available for use in the clinic.

\section{Inhaled Antibiotic Therapy in Non-CF Bronchiectasis}

In non-CF bronchiectasis, chronic airway infection and inflammation lead to symptoms of persistent cough and expectoration, and recurrent infective exacerbations produce progressive lung damage, resulting in the characteristic irreversible dilation of the bronchi. ${ }^{138}$ The incidence of non-CF bronchiectasis in the United States is estimated at 52 cases per $100,000 .{ }^{139}$ In severe cases, non-CF bronchiectasis leads to a decline in lung function, frequent hospitalizations, reduced quality of life, and increased mortality rates. ${ }^{140,141}$ The mortality from non-CF bronchiectasis ranges from 10 to $16 \%$ over an approximate 4 -y observation period. ${ }^{142}$

Pseudomonas aeruginosa, Moraxella catarrhalis and Haemophilus influenzae are frequently identified bacterial pathogens in sputum isolates from non-CF bronchiectasis patients. ${ }^{143} P$. aeruginosa infections are reported in as many as one fourth to one half of patients and are associated with the most severe forms of bronchiectasis with higher morbidity and mortality. ${ }^{140,141}$ Other less commonly identified pathogens include non-tuberculous mycobacteria and Gram-positive organisms (Streptococcus pneumoniae and Staphylococcus aureus). ${ }^{144-147}$ Isolation of P. aeruginosa has been identified as an independent predictor of accelerated lung function decline in patients with non-CF bronchiectasis. ${ }^{140,141,148}$

P. aeruginosa and other Gram-negative organisms are the primary targets for inhaled antibiotics in patients with non-CF bronchiectasis. Several classes of inhaled antibiotics, including aminoglycosides, cephalosporins, colistin, and fluoroquinolones, have been employed in patients with non-CF bronchiectasis with the premise that reducing the bacterial load could ameliorate the chronic inflammation and airway damage, reduce the frequency of exacerbations, and stem the resulting decline in lung function and quality of life. ${ }^{149,150}$ Administration by inhalation achieves higher airway concentrations of antibiotics compared with enteral or parenteral administration. Most of these antibiotics have a concentration-dependent killing effect, and the rationale is to hit hard and hit fast to maximize efficacy, reduce the chances for development of resistance, ${ }^{151}$ and decrease systemic toxicity compared with the use of intravenous antibiotic therapy.
Some inhaled antibiotics that are marketed for CF have also been evaluated for non-CF bronchiectasis. However, for reasons that remain unexplained, inhalation of tobramycin and colistin, which have been shown to be efficacious in patients with $\mathrm{CF}$, have not been effective in patients with non-CF bronchiectasis and have been associated with a higher frequency of adverse respiratory effects. ${ }^{152,153}$

Aztreonam for inhalation solution (AZLI, Cayston, Gilead Sciences, Foster City, California) is an inhaled antipseudomonal antibiotic. AIR-BX1 and AIR-BX2 were 2 double-blind, multi-center, randomized, placebo-controlled phase 3 trials, which included subjects age $>18 \mathrm{y}$ who had bronchiectasis and a history of positive sputum or bronchoscopic culture for target Gram-negative organisms. ${ }^{154}$ Subjects were randomized (1:1) to receive either AZLI or placebo. In both studies, 2 4-week courses of AZLI $(75 \mathrm{mg}$ ) or placebo (3 times daily; eFlow nebulizer) were each followed by a 4-week washout period. The primary end point was change from baseline quality of life-bronchiectasis respiratory symptoms scores at 4 weeks. Quality of life-bronchiectasis respiratory symptoms scores are $0-100$, with high scores representing few symptoms.

In AIR-BX1, 348 subjects were screened; 134 were randomly assigned to receive AZLI and 132 to receive placebo. In AIR-BX2, 404 subjects were screened; 136 were randomly assigned to receive AZLI and 138 to receive placebo. In AIR-BX1, the adjusted mean change from baseline quality of life-bronchiectasis respiratory symptoms score with AZLI at 4 weeks did not differ from placebo (0.8 [95\% CI 3.1-4.7], $P=.68)$, but there was a significant (4.6 [95\% CI 1.1-8.2], $P=.01$ ) difference in AIR-BX2. ${ }^{154}$ However, the 4.6-point difference in quality of life-bronchiectasis respiratory symptoms score after 4 weeks in AIR-BX2 was not considered to be clinically important. In both studies, the most commonly reported treatment-emergent adverse events (dyspnea, cough, and increased sputum) as well as discontinuations from adverse events were more common in the AZLI group than in the placebo group. ${ }^{154}$ AZLI treatment did not appear to provide significant clinical benefit in non-CF bronchiectasis, as measured by quality of life-bronchiectasis respiratory symptoms score.

DPI ciprofloxacin (one capsule of DPI ciprofloxacin [32.5 mg] twice daily, using a T-326 breath-actuated inhaler) is being developed as a long-term intermittent therapy to reduce the frequency of exacerbations in non-CF bronchiectasis patients colonized with respiratory bacterial pathogens. ${ }^{143,155,156}$ Early results with twice-daily inhaled ciprofloxacin by DPI administered in 12 cycles of $14 \mathrm{~d}$ on/14 d off found a reduction in the number of exacerbations compared with placebo (adjusted hazard ratio 0.53, $P<.001) .{ }^{157}$ Moreover, one trial (ORBIT-3), in which a dual-release formulation of ciprofloxacin combining liposomal ciprofloxacin for inhalation (150 mg in $3 \mathrm{~mL}$ ) with 
free ciprofloxacin (60 mg in $3 \mathrm{~mL}$ ) (Pulmaquin, Aradigm Corp, Hayward, California) was administered once a day, reported that the median time to first exacerbation was delayed by Pulmaquin compared with a placebo, but the results were not statistically significant. However, in the second trial, ORBIT-4, the median time to first exacerbation in subjects receiving Pulmaquin was significantly delayed ( $230 \mathrm{~d}$ vs $163 \mathrm{~d}$ ) compared with those receiving placebo. ${ }^{158}$ Further details of the results of these studies are forthcoming.

The use of inhaled antibiotics in patients with non-CF bronchiectasis is primarily directed at Gram-negative organisms, especially P. aeruginosa. Although several classes of inhaled antibiotics have been employed in patients with non-CF bronchiectasis, the results have been inconclusive, and further studies are needed to demonstrate their efficacy and safety in this clinical setting.

\section{Inhaled Interferon- $\gamma$ in Idiopathic Pulmonary Fibrosis}

IPF is a spontaneously occurring specific form of chronic fibrosing interstitial pneumonia limited to the lung and associated with a pattern of usual interstitial pneumonia on high-resolution computed tomography or histologic appearance on surgical lung biopsy. The efficacy and safety of inhaled interferon- $\gamma($ IFN- $\gamma$ ) was determined in 10 subjects with IPF. ${ }^{159}$ Subjects inhaled $100 \mu \mathrm{g}$ of IFN- $\gamma$ (Actimmune, InterMune, Brisbane, California; 2 million units or $100 \mu \mathrm{g} / 0.5 \mathrm{~mL}) 3$ times/week for a minimum of 80 weeks. The I-neb adaptive aerosol delivery system (Philips Respironics, Parsippany, New Jersey), a breath-actuated vibrating mesh nebulizer, was employed. ${ }^{160}$ Subjects tolerated inhaled IFN- $\gamma$ well, with no systemic adverse effects. In vivo lung deposition averaged $65.4 \pm 4.8 \%$ of the nebulizer charge. The slope of decline in total lung capacity and diffusion capacity for carbon monoxide $\left(\mathrm{D}_{\mathrm{LCO}}\right)$ reversed after beginning therapy. ${ }^{159}$ Inhaled IFN- $\gamma$ was found to be effectively delivered to the lung and was not associated with adverse effects.

One of those 10 subjects was able to obtain the drug and continued therapy for $7 \mathrm{y}$. For 5 months before beginning therapy, his PFTs demonstrated a steady decline in total lung capacity and $\mathrm{D}_{\mathrm{LCO}}$, a finding consistent with active pulmonary fibrosis. After he started to receive $100 \mu \mathrm{g}$ of Actimmune (Horizon Pharma, Deerfield, Illinois), 3 times/week via vibrating mesh nebulizer (I-neb from 2007 to 2010; U22 [Omron Healthcare, Bannockburn, Illinois] from 2011 to 2014), his PFTs improved. The $\mathrm{D}_{\mathrm{LCO}}$ showed the greatest change, with an increase to $81 \%$ of predicted at $1.5 \mathrm{y}$ of therapy and a slow decline to $69 \%$ of predicted at the time of the last observation (Fig. 2). ${ }^{161}$

These results suggest that inhalation of IFN- $\gamma$ in patients with IPF may prevent the decline in lung function that is typically observed in these patients. Comparison with data before the initiation of therapy revealed that the rate of decline in lung function was reversed by inhalation of IFN- $\gamma$. It is remarkable that this subject actually improved his $\mathrm{D}_{\mathrm{LCO}}$ significantly after starting treatment. Further studies will hopefully shed more light on the efficacy and safety of inhaled IFN- $\gamma$ in patients with IPF.

\section{Food Flavoring in E-Cigarettes}

E-cigarettes have become enormously popular since their introduction in the early part of the 21 st century. It is estimated that $12.6 \%$ of American adults ${ }^{162}$ and $13.4 \%$ of high school students ${ }^{163}$ have tried them at least once. Although e-cigarette vapor contains no detectable amounts of carbonyls, polycyclic aromatic hydrocarbons, tobaccospecific nitrosamines, volatile organic compounds, or other toxicants, ${ }^{164}$ there is an active debate about the effects of e-cigarette use on people's health. Besides considerations about the safety of e-cigarettes, there are increasing concerns that their widespread use may lead to a renormalization of smoking behavior, especially in teenagers and young adults. ${ }^{165}$ The current knowledge base is inadequate to address these important health-related and social concerns, and more extensive studies are needed.

Benzaldehyde, an aromatic chemical utilized in food and cosmetics, is found in various flavorings and is one of the chemicals in e-cigarettes. Whereas combustion cigarettes are banned from having non-menthol flavorings, noncigarette tobacco products, such as e-cigarettes, are not. ${ }^{166}$ Benzaldehyde has minimal risks when associated with dermal and oral use but has been known to act as an irritant to the eyes and mucous membranes of the respiratory passages with occupational exposure. ${ }^{167}$ These effects of benzaldehyde have raised concerns about the toxicity of flavored e-cigarette aerosols. ${ }^{168}$

To determine the level of exposure to benzaldehyde in e-cigarette flavored solutions, Kosmider et al ${ }^{169}$ measured benzaldehyde in 145 nicotine-containing solutions using an automatic smoking simulator set to an inhalation time of $1.8 \mathrm{~s}$, puff volume of $70 \mathrm{~mL}$, and 17-s intervals between puffs for 2 series of 15 puffs separated by 5 min. They analyzed their results with a method proposed by the United States Environmental Protection Agency. ${ }^{170}$ The investigators observed that the highest yield of benzaldehyde (5.129-141.2 $\mu \mathrm{g} / 30 \mathrm{puffs})$ was in cherry-flavored products. ${ }^{169}$ The levels of benzaldehyde in cherry-flavored cigarettes significantly surpassed the lower limit of quantitation at $0.025 \mu \mathrm{g} / 30$ puffs and were higher than the inhaled dose of benzaldehyde in non-cherry-flavored solutions $(0.025-10.27 \mu \mathrm{g} / 30 \mathrm{puffs})$ and in combustion cigarettes (0.5-4.5 $\mu \mathrm{g} /$ cigarette). ${ }^{171}$ The benzaldehyde content of cherry-flavored nicotine solutions was significantly higher than for other solutions tested $(P<.001) .{ }^{169}$ Thus, users of 


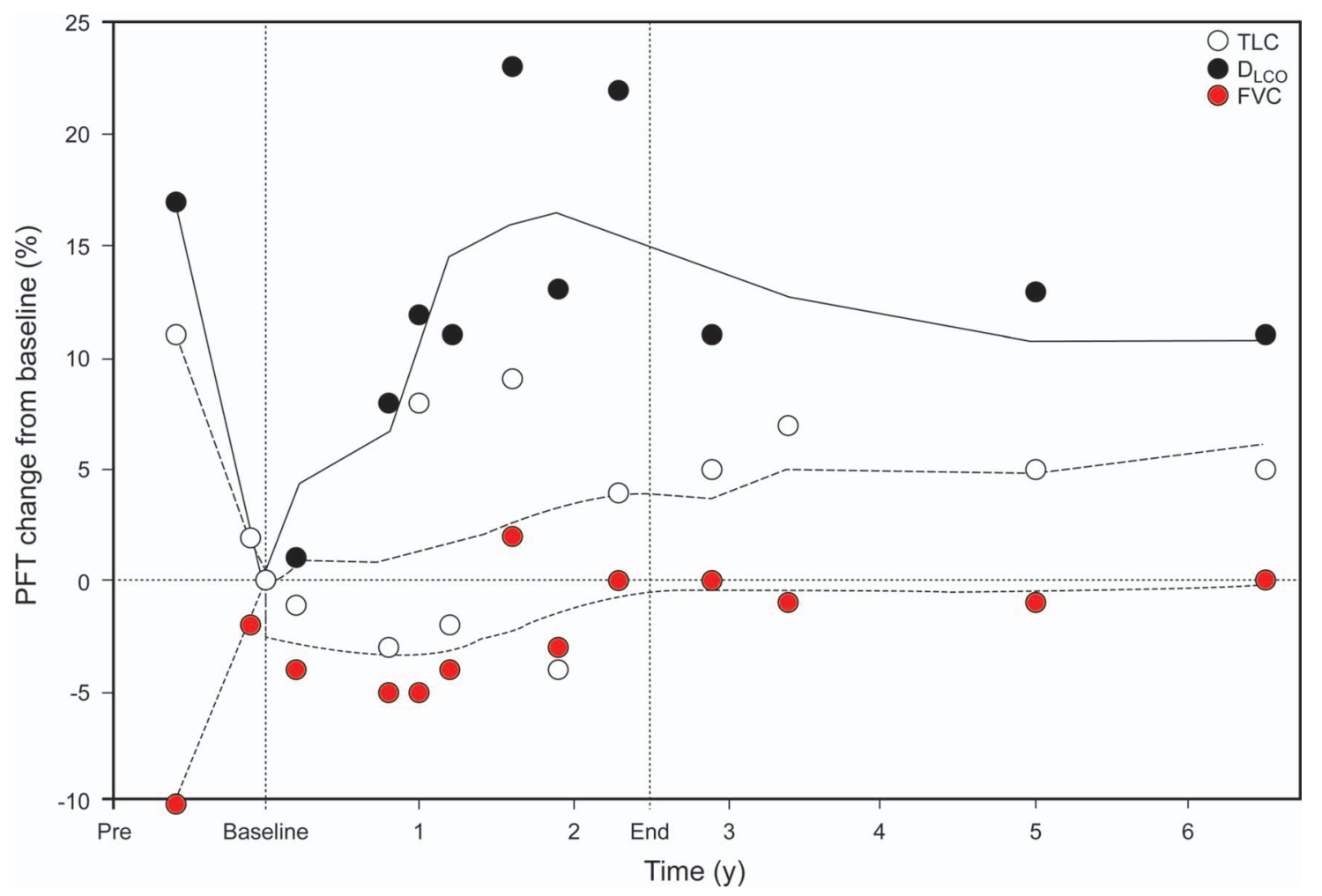

Fig. 2. Pulmonary function test (PFT) data over time, $0 \%$ indicates PFT at start of inhaled IFN- $\gamma$. Points are actual data, lines generated by smoothing. Baseline is defined as start of inhaled IFN- $\gamma$. Observations before baseline demonstrate decreasing TLC and DLCO. Forced vital capacity stabilized after start of therapy. Vertical lines show baseline and end of inhaled IFN- $\gamma$. From Reference 161, with permission.

cherry-flavored e-cigarettes could inhale significantly higher doses of benzaldehyde compared with other flavored products. Although this study showed elevated levels of benzaldehyde in cherry-flavored products, there is no information on the long-term physiological effects of smoking e-cigarettes with full flavoring agents. Shahab et al ${ }^{172}$ recently reported that use of e-cigarettes reduced the exposure to carcinogens and volatile organic compounds compared with the use of combustible cigarettes. However, the long-term effects of e-cigarettes with food flavorings versus combustion cigarettes need to be explored in more detail.

\section{Summary}

Inhaled therapies are gaining increasing popularity in a variety of clinical settings. Here some recent salient publications related to aerosol therapy are discussed. Longacting antimuscarinic agents, such as tiotropium, have been proposed for treatment of asthma. Somewhat surprisingly, a $2.5-\mu \mathrm{g}$ once daily dose of tiotropium administered with the Respimat was found to have greater efficacy than the 5.0- $\mu \mathrm{g}$ daily dose that is approved for use in COPD. The demonstration of a reverse dose response serves to caution us that administering more drug, which has been the goal of aerosol therapy in many respiratory diseases, does not always yield the best clinical outcomes. Small-airway inflammation contributes to pathogenesis of asthma, especially severe asthma, but there has been no consensus on whether the use of small-particle aerosols to target small airways inflammation improves asthma control. A recent review of this issue did not provide conclusive evidence in favor of using small-particle aerosols but noted that clinical outcomes of patients with symptomatic asthma have been better in real-life studies when fine-particle aerosols were compared with conventional (large-particle) aerosols. In patients with COPD, dual bronchodilator therapy with a long-acting antimuscarinic agent/LABA combination provides greater bronchodilation than the individual components. The FLAME study provides data to show the superiority of a long-acting antimuscarinic agent/LABA combination in preventing exacerbations compared with an ICS/LABA combination. Another study in children with asthma and adults with asthma or COPD attempted to clarify the relative importance of peak inhalation flow, pressure change, acceleration of flow, and inhalation volume when they inhaled from DPIs with varying resistances. The peak inhalation flow must be considered in the context of the DPI resistance, and it is necessary to achieve a minimum peak inhalation flow below which a DPI does 
not function appropriately. Replacement of the defective CFTR gene in patients with CF with a normal gene has been attempted for several years. Investigators from the United Kingdom have shown modest success with a plasmid encoding the CFTR gene packaged within a non-viral vector. Monthly inhalation of the formulation over a period of $1 \mathrm{y}$ stabilized the pulmonary function in subjects with $\mathrm{CF}$ compared with subjects receiving placebo inhalation. Also discussed are recent studies of inhaled antibiotics in subjects with non-CF bronchiectasis and inhaled IFN- $\gamma$ in subjects with idiopathic pulmonary fibrosis. The results of these studies have been encouraging, but their use remains investigational at the present time. Many people smoke e-cigarettes with the belief that the health risks associated with their use are much less than those associated with tobacco cigarettes. Some e-cigarettes contain food flavorings, and benzaldehyde is present in food flavorings. The highest levels of benzaldehyde were shown in the vapor from cherry flavored cigarettes, raising concerns about the safety of some food flavorings in e-cigarettes.

\section{REFERENCES}

1. Dolovich MB, Dhand R. Aerosol drug delivery: developments in device design and clinical use. Lancet 2011;377(9770):1032-1045.

2. Dhand R. Aerosol therapy for asthma. Curr Opin Pulm Med 2000; 6(1):59-70.

3. Global Initiative for Asthma. 2017 GINA report, global strategy forasthmamanagementandprevention. http://ginasthma.org/2017-ginareport-global-strategy-for-asthma-management-and-prevention/. Accessed March 14, 2017.

4. Bateman ED, Boushey HA, Bousquet J, Busse WW, Clark TJ, Pauwels RA, et al. Can guideline-defined asthma control be achieved? the Gaining Optimal Asthma controL study. Am J Respir Crit Care Med 2004;170(8):836-844.

5. Demoly P, Paggiaro P, Plaza V, Bolge SC, Kannan H, Sohier B, Adamek L. P. Prevalence of asthma control among adults in France, Germany, Italy, Spain and the UK. Eur Respir Rev 2009;18(112): 105-112.

6. Partridge MR, Dal Negro RW, Olivieri DM. Understanding patients with asthma and COPD: insights from a European study. Prim Care Respir J 2011;20(3):315-323.

7. Peters SP, Kunselman SJ, Icitovic N, Moore WC, Pascual R, Ameredes BT, et al. Tiotropium bromide step-up therapy for adults with uncontrolled asthma. N Engl J Med 2010;363(18):1715-1726.

8. Kerstjens HA, Disse B, Schröder-Babo W, Bantje TA, Gahlemann $\mathrm{M}$, Sigmund R, et al. Tiotropium improves lung function in patients with severe uncontrolled asthma: a randomized controlled trial. J Allergy Clin Immunol 2011;128(2):308-314.

9. Bateman ED, Kornmann O, Schmidt P, Pivovarova A, Engel M, Fabbri LM. Tiotropium is noninferior to salmeterol in maintaining improved lung function in B16-Arg/Arg patients with asthma. J Allergy Clin Immunol 2011;128(2):315-322.

10. Beeh KM, Moroni-Zentgraf P, Ablinger O, Hollaenderova Z, Unseld A, Engel M, Korn S. Tiotropium Respimat in asthma: a double-blind, randomised, dose-ranging study in adult patients with moderate asthma. Respir Res 2014;15(Can't get issue from record): 61.
11. Kerstjens HA, Engel M, Dahl R, Paggiaro P, Beck E, Vandewalker $\mathrm{M}$, et al. Tiotropium in asthma poorly controlled with standard combination therapy. N Engl J Med 2012;367(13):1198-1207.

12. Kerstjens HA, Casale TB, Bleecker ER, Meltzer EO, Pizzichini E, Schmidt O, et al. Tiotropium or salmeterol as add-on therapy to inhaled corticosteroids for patients with moderate symptomatic asthma: two replicate, double-blind, placebo-controlled, parallel-group, active-comparator, randomized trials. Lancet Respir Med 2015;3(5): 367-376.

13. Timmer W, Moroni-Zentgraf P, Cornelissen P, Unseld A, Pizzichini E, Buhl R. W. Once-daily tiotropium Respimat $5 \mathrm{mg}$ is an efficacious 24-hour bronchodilator in adults with symptomatic asthma. Respir Med 2015;109(3):329-338.

14. Ohta K, Ichinose M, Tohda Y, Engel M, Moroni-Zentgraf P, Kunimitsu S, et al. Long-term once-daily tiotropium Respimat is well tolerated and maintains efficacy over 52 weeks in patients with symptomatic asthma in Japan: a randomised, placebo-controlled study, PLoS One 2015;10(4):e0124109.

15. Paggiaro P, Halpin DM, Buhl R, Engel M, Zubek VB, Blahova Z, et al. The effect of tiotropium in symptomatic asthma despite lowto medium-dose inhaled corticosteroids: a randomized controlled trial. J Allergy Clin Immunol Pract 2016;4(1):104-113.e2.

16. Kerstjens HA, Moroni-Zentgraf P, Tashkin DP, Dahl R, Paggiaro P, Vandewalker M, et al. Tiotropium improves lung function, exacerbation rate, and asthma control, independent of baseline characteristics including age, degree of airway obstruction, and allergic status. Respir Med 2016;117:198-206.

17. Chin SJ, Durmowicz AG, Chowdhury BA. Tiotropium Respimat is effective for the treatment of asthma at a dose lower than that for chronic obstructive pulmonary disease. Ann Am Thorac Soc 2016; 13(2):173-179.

18. Bel EH. Tiotropium for asthma: promise and caution. N Engl J Med 2012;367(13):1257-1259.

19. Global Initiative for Chronic Obstructive Lung Disease. GOLD 2017 global strategy for diagnosis, management, and prevention of COPD. 2017. http://goldcopd.org/gold-2017-global-strategy-diagnosismanagement-prevention-copd/. Accessed March 14, 2017.

20. Calverley PM, Könen-Bergmann M, Richard F, Bell S, Hohlfeld JM. Tiotropium Respimat versus HandiHaler comparison of bronchodilator efficacy of various doses in clinical trials. Adv Ther 2016;33(5):786-793.

21. Darquenne C. Aerosol deposition in health and disease. J Aerosol Med Pulm Drug Deliv 2012;25(3):140-147.

22. Dolovich M, Ruffin RE, Roberts R, Newhouse MT. Optimal delivery of aerosols from metered dose inhalers. Chest 1981;80(6 Suppl):911-915.

23. Anderson P. Use of Respimat Soft Mist inhaler in COPD patients. Int J Chron Obstruct Pulmon Dis 2006;1(3):251-259.

24. Nelson HS, Spector SL, Whitsett TL, George RB, Dwek JH. The bronchodilator response to inhalation of increasing doses of aerosolized albuterol. J Allergy Clin Immunol 1983;72(4):371-375.

25. Barnes PJ, Pride NB. Dose-response curves to inhaled $\beta$-adrenoceptor antagonists in normal and asthmatic subjects. Br J Clin Pharmacol 1983;15(6):677-682.

26. Corris PA, Neville E, Nariman S, Gibson GJ. Dose response study of inhaled salbutamol powder in chronic airflow obstruction. Tho$\operatorname{rax} 1$ 1983;38(4):292-296.

27. Jenkins SC, Heaton RW, Fulton TJ, Moxham J. Comparison of domiciliary nebulized salbutamol and salbutamol from a metereddose inhaler in stable chronic airflow limitation. Chest 1987;91(6): 804-807.

28. Jenkins SC, Moxham J. High dose salbutamol in chronic bronchitis: comparison of $400 \mu \mathrm{g}, 1 \mathrm{mg}, 1.6 \mathrm{mg}, 2 \mathrm{mg}$ and placebo delivered by rotahaler. Br J Dis Chest 1987;81(3):242-247. 
29. Vathenen AS, Britton JR, Ebden P, Cookson JB, Wharrad HJ, Tattersfield AE. High dose inhaled albuterol in severe chronic airflow limitation. Am Rev Respir Dis 1988;138(4):850-855.

30. Jaeschke R, Guyatt GH, Cook D, Morris J, Willan A, McIlroy W, et al. The effect of increasing doses of $\beta$-agonists on airflow in patients with chronic airflow limitation. Respir Med 1993;87(6): 433-438.

31. Georgopoulos D, Wong D, Anthonisen NR. Tolerance to $\beta 2$-agonists in patients with chronic obstructive pulmonary disease. Chest 1990;97(2):280-284

32. Tan CK, Say GQ, Geake JB. Long-term safety of tiotropium delivered by Respimat SoftMist inhaler: patient selection and special considerations. Ther Clin Risk Manag 2016;12:1433-1444.

33. Pauwels RA, Löfdahl CG, Postma DS, Tattersfield AE, O'Byrne P, Barnes PJ, Ullman A. Effect of inhaled formoterol and budesonide on exacerbations of asthma: Formoterol and Corticosteroids Establishing Therapy (FACET) International Study Group. N Engl J Med 1997;337(20):1405-1411.

34. O'Byrne PM, Naya IP, Kallen A, Postma DS, Barnes PJ. Increasing doses of inhaled corticosteroids compared to adding long-acting inhaled $\beta 2$-agonists in achieving asthma control. Chest 2008;134(6): 1192-1199.

35. Hamid Q. Pathogenesis of small airways in asthma. Respiration 2012;84(1):4-11.

36. in 't Veen JC, Beekman AJ, Bel EH, Sterk PJ. Recurrent exacerbations in severe asthma are associated with enhanced airway closure during stable episodes. Am J Respir Crit Care Med 2000; 161(6):1902-1906

37. Anderson WJ, Zajda E, Lipworth BJ. Are we overlooking persistent small airways dysfunction in community-managed asthma? Ann Allergy Asthma Immunol 2012;109(3):185-189.e2.

38. Scichilone N, Battaglia S, Taormina S, Modica V, Pozzecco E, Bellia V. Alveolar nitric oxide and asthma control in mild untreated asthma. J Allergy Clin Immunol 2013;131(6):1513-1517.

39. Perez T, Chanez P, Dusser D, Devillier P. Small airway impairment in moderate to severe asthmatics without significant proximal airway obstruction. Respir Med 2013;107(11):1667-1674.

40. Usmani OS. Small airway disease in asthma: pharmacological considerations. Curr Opin Pulm Med 2015;21(1):55-67.

41. Lavorini F, Pedersen S, Usmani OS. Dilemmas, confusion, and misconceptions related to small airways directed therapy. Chest 2016. doi: 10.1016/j.chest.2016.07.035 [Epub ahead of print].

42. Leach CL, Kuehl PJ, Chand R, Ketai L, Norenberg JP, McDonald JD. Characterization of respiratory deposition of fluticasone-salmeterol hydrofluoroalkane-134a and hydrofluoroalkane-134a beclomethasone in asthmatic patients. Ann Allergy Asthma Immunol 2012;108(3):195-200.

43. Martin RJ. Therapeutic significance of distal airway inflammation in asthma. J Allergy Clin Immunol 2002;109(2 Suppl):S447-S460.

44. Yang TT, Li S, Wyka B, Kenyon D. Drug delivery performance of the mometasone furoate dry powder inhaler. J Aerosol Med 2001; 14(4):487-494.

45. Nicolini G, Scichilone N, Bizzi A, Papi A, Fabbri LM. Beclomethasone/formoterol fixed combination for the management of asthma: patient considerations. Ther Clin Risk Manag 2008;4(5): 855-864.

46. Cripps A, Riebe M, Schulze M, Woodhouse R. Pharmaceutical transition to non-CFC pressurized metered dose inhalers. Respir Med 2000;94(Suppl B):S3-S9.

47. Acerbi D, Brambilla G, Kottakis I. Advances in asthma and COPD management: delivering CFC-free inhaled therapy using Modulite technology. Pulm Pharmacol Ther 2007;20(3):290-303.

48. Leach CL, Davidson PJ, Boudreau RJ. Improved airway targeting with the CFC-free HFA-beclomethasone metered-dose inhaler com- pared with CFC-beclomethasone. Eur Respir J 1998;12(6):13461353.

49. Leach CL, Bethke TD, Boudreau RJ, Hasselquist BE, Drollmann A, Davidson P, Wurst W. Two-dimensional and three dimensional imaging show ciclesonide has high lung deposition and peripheral distribution: a nonrandomized study in healthy volunteers. J Aerosol Med 2006;19(2):117-126.

50. Biddiscombe MF, Usmani OS, Barnes PJ. A system for the production and delivery of monodisperse salbutamol aerosols to the lungs. Int J Pharm 2003;254(2):243-253.

51. Usmani OS, Biddiscombe MF, Barnes PJ. Regional lung deposition and bronchodilator response as a function of $\beta 2$-agonist particle size. Am J Respir Crit Care Med 2005;172(12):1497-1504.

52. Newman S, Salmon A, Nave R, Drollmann A. High lung deposition of $99 \mathrm{mTc}$-labeled ciclesonide administered via HFA-MDI to patients with asthma. Respir Med 2006;100(3):375-384.

53. Boulet LP, Drollmann A, Magyar P, Timar M, Knight A, Engelstätter R, Fabbri L. Comparative efficacy of once-daily ciclesonide and budesonide in the treatment of persistent asthma. Respir Med 2006;100(5):785-794.

54. Boulet LP, Bateman ED, Voves R, Müller T, Wolf S, Engelstätter R. A randomized study comparing ciclesonide and fluticasone propionate in patients with moderate persistent asthma. Respir Med 2007;101(8):1677-1686.

55. Barnes N, Price D, Colice G, Chisholm A, Dorinsky P, Hillyer EV, et al. Asthma control with extrafine-particle hydrofluoroalkanebeclometasone vs. large-particle chlorofluorocarbon-beclometasone: a realworld observational study. Clin Exp Allergy 2011;41(1):1521-1532.

56. Colice G, Martin RJ, Israel E, Roche N, Barnes N, Burden A, et al. Asthma outcomes and costs of therapy with extrafine beclomethasone and fluticasone. J Allergy Clin Immunol 2013;132(1):45-54.

57. Price D, Martin RJ, Barnes N, Dorinsky P, Israel E, Roche N, et al. Prescribing practices and asthma control with hydrofluoroalkanebeclomethasone and fluticasone: a real-world observational study. J Allergy Clin Immunol 2010;126(3):511-518.e1-e10.

58. Price D, Thomas M, Haughney J, Lewis RA, Burden A, von Ziegenweidt J, et al. Real-life comparison of beclomethasone dipropionate as an extrafine- or larger-particle formulation for asthma. Respir Med 2013;107(7):987-1000.

59. Allegra L, Cremonesi G, Girbino G, Ingrassia E, Marsico S, Nicolini G, et al. PRISMA (PRospectIve Study on asthMA control) Study Group. Real-life prospective study on asthma control in Italy: cross-sectional phase results. Respir Med 2012;106(2):205-214.

60. Müller V, Gálffy G, Eszes N, Losonczy G, Bizzi A, Nicolini G, et al. Asthma control in patients receiving inhaled corticosteroid and long-acting $\beta 2$-agonist fixed combinations: a real-life study comparing dry powder inhalers and a pressurized metered dose inhaler extrafine formulation. BMC Pulm Med 2011;11:40.

61. Popov TA, Petrova D, Kralimarkova TZ, Ivanov Y, Popova T, Peneva M, et al. Real life clinical study design supporting the effectiveness of extra-fine inhaled beclomethasone/formoterol at the level of small airways of asthmatics. Pulm Pharmacol Ther 2013;26(6):624-629.

62. Price D, Small I, Haughney J, Ryan D, Gruffydd-Jones K, Lavorini F, et al. Clinical and cost effectiveness of switching asthma patients from fluticasone-salmeterol to extra-fine particle beclometasoneformoterol: a retrospective matched observational study of realworld patients. Prim Care Respir J 2013;22(4):439-448.

63. Terzano C, Cremonesi G, Girbino G, Ingrassia E, Marsico S, Nicolini $\mathrm{G}$, et al. 1-Year prospective real life monitoring of asthma control and quality of life in Italy. Respir Res 2012;13:112.

64. Ohbayashi H, Adachi M. Hydrofluoroalkane-beclomethasone dipropionate effectively improves airway eosinophilic inflammation 
including the distal airways of patients with mild to moderate persistent asthma as compared with fluticasone propionate in a randomized open double-cross study. Allergol Int 2008;57(3):231-239.

65. Wheaton AG, Cunningham TJ, Ford ES, Croft JB, Centers for Disease Control and Prevention (CDC). Employment and activity limitations among adults with chronic obstructive pulmonary disease-United States, 2013. MMWR Morb Mortal Wkly Rep 2015; 64(11):289-295.

66. Mannino DM, Gagnon RC, Petty TL, Lydick E. Obstructive lung disease and low lung function in adults in the United States: data from the National Health and Nutrition Examination Survey 19881994. Arch Intern Med 2000;160(11):1683-1689.

67. Mathers CD, Loncar D. Projections of global mortality and burden of disease: from 2002 to 2030. PLoS Med 2006;3(11):e442.

68. Tashkin DP, Celli B, Senn S, Burkhart D, Kesten S, Menjoge S, Decramer M. A 4-year trial of tiotropium in chronic obstructive pulmonary disease. N Engl J Med 2008;359(15):1543-1554.

69. Kerwin E, Hébert J, Gallagher N, Martin C, Overend T, Alagappan VK, et al. Efficacy and safety of NVA237 versus placebo and tiotropium in patients with COPD: the GLOW2 study. Eur Respir J 2012;40(5):1106-1114.

70. Calverley PM, Anderson JA, Celli B, Ferguson GT, Jenkins C, Jones PW, et al. Salmeterol and fluticasone propionate and survival in chronic obstructive pulmonary disease. N Engl J Med 2007; 356(8):775-789.

71. Wedzicha JA, Buhl R, Lawrence D, Young D. Monotherapy with indacaterol once daily reduces the rate of exacerbations in patients with moderate-to-severe COPD: post-hoc pooled analysis of 6 months data from three large phase III trials. Respir Med 2015; 109(1):105-111.

72. Szafranski W, Cukier A, Ramirez A, Menga G, Sansores R, Nahabedian S, et al. Efficacy and safety of budesonide/formoterol in the management of chronic obstructive pulmonary disease. Eur Respir J 2003;21(1):74-81.

73. Calverley PM, Boonsawat W, Cseke Z, Zhong N, Peterson S, Olsson $\mathrm{H}$. Maintenance therapy with budesonide and formoterol in chronic obstructive pulmonary disease. Eur Respir J 2003;22(6): 912-919.

74. Wedzicha JA, Calverley PM, Seemungal TA, Hagan G, Ansari Z, Stockley RA. The prevention of chronic obstructive pulmonary disease exacerbations by salmeterol/fluticasone propionate or tiotropium bromide. Am J Respir Crit Care Med 2008;177(1):19-26.

75. Price D, Yawn B, Brusselle G, Rossi A. Risk-to-benefit ratio of inhaled corticosteroids in patients with COPD. Prim Care Respir J 2013;22(1):92-100.

76. Crim C, Calverley PM, Anderson JA, Celli B, Ferguson GT, Jenkins $\mathrm{C}$, et al. Pneumonia risk in COPD patients receiving inhaled corticosteroids alone or in combination: TORCH study results. Eur Respir J 2009;34(3):641-647.

77. Calverley PM, Stockley RA, Seemungal TA, Hagan G, Willits LR, Riley JH, et al. Reported pneumonia in patients with COPD: findings from the INSPIRE study. Chest 2011;139(3):505-512.

78. Zhong N, Wang C, Zhou X, Zhang N, Patalano F, Humphries M, et al. Late-breaking abstract: efficacy and safety of once-daily QVA149 compared with twice-daily salmeterol/fluticasone combination (SFC) in patients with COPD: the LANTERN study. Eur Respir J 2014;44:P2815.

79. Beeh KM, Korn S, Beier J, Jadayel D, Henley M, D'Andrea P, Banerji D. Effect of QVA149 on lung volumes and exercise tolerance in COPD patients: the BRIGHT study. Respir Med 2014; 108(4):584-592.

80. Drollmann A, Brown M, Sechaud R, Perry S, Hara H, Jones I, Febbraro S. Effect of dual bronchodilation with QVA149 on car- diac safety in healthy volunteers. Int J Clin Pharmacol Ther 2014; 52(5):369-380.

81. Mahler DA, Decramer M, D’Urzo A, Worth H, White T, Alagappan VK, et al. Dual bronchodilation with QVA149 reduces patientreported dyspnoea in COPD: the BLAZE study. Eur Respir J 2014; 43(6): 1599-1609.

82. Vincken W, Aumann J, Chen H, Henley M, McBryan D, Goyal P. Efficacy and safety of coadministration of once-daily indacaterol and glycopyrronium versus indacaterol alone in COPD patients: the GLOW6 study. Int J Chron Obstruct Pulmon Dis 2014;9:215-228.

83. Bateman ED, Ferguson GT, Barnes N, Gallagher N, Green Y, Henley M, Banerji D. Dual bronchodilation with QVA149 versus single bronchodilator therapy: the SHINE study. Eur Respir J 2013; 42(6): 1484-1494.

84. Asai K, Minakata Y, Hirata K, Fukuchi Y, Kitawaki T, Ikeda K, Banerji D. QVA149 once-daily is safe and well tolerated and improves lung function and health status in Japanese patients with COPD: the ARISE study. Eur Respir J 2013;42:P3392.

85. Dahl R, Jadayel D, Alagappan VK, Chen H, Banerji D. Efficacy and safety of QVA149 compared to the concurrent administration of its monocomponents indacaterol and glycopyrronium: the BEACON study. Int J Chron Obstruct Pulmon Dis 2013;8:501-508.

86. Dahl R, Chapman KR, Rudolf M, Mehta R, Kho P, Alagappan VK, et al. Safety and efficacy of dual bronchodilation with QVA149 in COPD patients: the ENLIGHTEN study. Respir Med 2013;107(10): 1558-1567.

87. Vogelmeier CF, Bateman ED, Pallante J, Alagappan VK, D'Andrea P, Chen H, Banerji D. Efficacy and safety of once-daily QVA149 compared with twice-daily salmeterol-fluticasone in patients with chronic obstructive pulmonary disease (ILLUMINATE): a randomised, double-blind, parallel group study. Lancet Respir Med 2013;1(1):51-60.

88. Wedzicha JA, Decramer M, Ficker JH, Niewoehner DE, Sandström $\mathrm{T}$, Taylor AF, et al. Analysis of chronic obstructive pulmonary disease exacerbations with the dual bronchodilator QVA149 compared with glycopyrronium and tiotropium (SPARK): a randomised, double-blind, parallel-group study. Lancet Respir Med 201(3)3;1: 199-209.

89. van Noord JA, Buhl R, Laforce C, Martin C, Jones F, Dolker M, and Overend T. QVA149 demonstrates superior bronchodilation compared with indacaterol or placebo in patients with chronic obstructive pulmonary disease. Thorax 2010;65(12):1086-1091.

90. Wedzicha JA, Banerji D, Chapman KR, Vestbo J, Roche N, Ayers $\mathrm{RT}$, et al. Indacaterol-glycopyrronium versus salmeterol-fluticasone for COPD. N Engl J Med 2016;374(23):2222-2234.

91. Restrepo RD, Tate A. Chapter 9.2: inhalation therapy for COPD. In: Dhand R, editor. ISAM textbook of aerosol medicine. Knoxville, Tennessee: International Society for Aerosols in Medicine; 2016:e1-e78.

92. Hurst JR, Vestbo J, Anzueto A, Locantore N, Müllerova H, TalSinger R, et al. Evaluation of CLtIPSEI: susceptibility to exacerbation in chronic obstructive pulmonary disease. N Engl J Med 2010;363(12):1128-1138.

93. Wedzicha JA, Dahl R, Buhl R, Schubert-Tennigkeit A, Chen H, D'Andrea P, et al. Pooled safety analysis of the fixed-dose combination of indacaterol and glycopyrronium (QVA149), its monocomponents, and tiotropium versus placebo in COPD patients. Respir Med 2014;108(10):1498-1507.

94. Mahler DA, Kerwin E, Ayers T, Fowler-Taylor A, Maitra S, Thach C, et al. FLIGHT1 and FLIGHT2: efficacy and safety of QVA149 (indacaterol/glycopyrrolate) versus its monocomponents and placebo in patients with chronic obstructive pulmonary disease. Am J Respir Crit Care Med 2015;192(9):1068-1079. 
95. Beeh KM, Burgel PR, Franssen FM, Lopez-Campos JL, Loukides $\mathrm{S}$, Hurst JR, et al. How do dual long-acting bronchodilators prevent exacerbations of chronic obstructive pulmonary disease? Am J Respir Crit Care Med 2016. doi: 10.1164/rccm.201609-1794CI [Epub ahead of print].

96. Laube BL, Janssens HM, de Jongh FH, Devadason SG, Dhand R, Diot $\mathrm{P}$, et al. What the pulmonary specialist should know about the new inhalation therapies. Eur Respir J 2011;37(6):1308-1417.

97. Chrystyn H, Price D. Not all asthma inhalers are the same: factors to consider when prescribing an inhaler. Prim Care Respir J 2009; 18(4):243-249.

98. Clark AR, Hollingworth AM. The relationship between powder inhaler resistance and peak inspiratory conditions in healthy volunteers-implications for in vitro testing. J Aerosol Med 1993;6(2): 99-110.

99. Clark AR. The role of inspiratory pressures in determining the flow rates through dry powder inhalers: a review. Curr Pharm Des 2015; 21(27):3974-3983.

100. Prime D, de Backer W, Hamilton M, Cahn A, Preece A, Kelleher $\mathrm{D}$, et al. Effect of disease severity in asthma and chronic obstructive pulmonary disease on inhaler specific inhalation profiles through the ELLIPTA dry powder inhaler. J Aerosol Med Pulm Drug Deliv 2015;28(6):486-497.

101. Chrystyn H. Is inhalation rate important for a dry powder inhaler? Using the In-Check Dial to identify these rates. Respir Med 2003; 97(2):181-187.

102. Weers J, Clark A. The impact of inspiratory flow rate on drug delivery to the lungs with dry powder inhalers. Pharm Res 2017; 34(3):507-528.

103. Palander A, Mattila T, Karka M, Muttonen E. In-vitro comparison of three salbutamol containing multidose dry powder inhalers. Clin Drug Invest 2000;20(1):25-33.

104. Borgström L. On the use of dry powder inhalers in situations perceived as constrained. J Aerosol Med 2001;14(3):281-87.

105. Srichana T, Martin GP, Marriott C. Dry powder inhalers: the influence of device resistance and powder formulation on drug and lactose deposition in vitro. Eur J Pharm Sci 1998;7(1):73-80.

106. Pedersen S, Hansen OR, Fuglsang G. Influence of inspiratory flow rate upon the effect of a Turbuhaler. Arch Dis Child 1990;65(3): 308-310.

107. Nielsen KG, Auk IL, Bojsen K, Ifversen M, Klug B, Bisgaard H. Clinical effect of Diskus dry-powder inhaler at low and high inspiratory flow rates in asthmatic children. Eur Respir J 1998;11(2): 350-354.

108. Nadarassan DK, Assi KH, Chrystyn H. Aerodynamic characteristics of a dry powder inhaler at low inhalation flows using a mixing inlet with an Andersen Cascade Impactor. Eur J Pharm Sci 2010; 39(5):348-354.

109. Engel T, Scharling B, Skovsted B, Heinig JH. Effects, side effects and plasma concentrations of terbutaline in adult asthmatics after inhaling from a dry powder inhaler device at different inhalation flows and volumes. Br J Clin Pharmacol 1992;33(4):439-444.

110. Nielsen KG, Skov M, Klug B, Ifversen M, Bisgaard H. Flowdependent effect of formoterol dry-powder inhaled from the Aerolizer. Eur Respir J 1997;10(9):2105-2109.

111. Azouz W, Chrystyn H. Clarifying the dilemmas about inhalation techniques for dry powder inhalers: integrating science with clinical practice. Prim Care Respir J 2012;21(2):208-213.

112. Everard ML, Devadason SG, Le Souëf PN. Flow early in the inspiratory manoeuvre affects the aerosol particle size distribution from a Turbuhaler. Respir Med 1997;91(10):624-628.

113. Kamin WE, Genz T, Roeder S, Scheuch G, Trammer T, Juenemann R, Cloes RM. Mass output and particle size distribution of glucocorticosteroids emitted from different inhalation devices depending on various inspiratory parameters. J Aerosol Med 2002; 15(1):65-73.

114. Amirav I, Newhouse MT, Mansour Y. Measurement of peak inspiratory flow with in-check dial device to simulate low-resistance (Diskus) and high-resistance (Turbohaler) dry powder inhalers in children with asthma. Pediatr Pulmonol 2005;39(5):447-451.

115. Alaboud A, Assi KH, Chrystyn H. In vitro characterization of the emitted dose from the foradil Aerolizer to identify the influence of inhalation flow, inhalation volume and the number of inhalations per dose. Respir Drug Delivery 2010;3:803-806.

116. Azouz W, Chetcuti P, Hosker HSR, Saralaya D, Stephenson J, Chrystyn $\mathrm{H}$. The inhalation characteristics of patients when they use different dry powder inhalers. J Aerosol Med Pulm Drug Deliv 2015;28(1):35-42.

117. Chrystyn H, Azouz W, Tarsin W. Chapter 6.4: dry powder inhalers-from bench to bedside. In: Dhand R, editor. ISAM textbook of aerosol medicine. Knoxville, Tennessee: International Society for Aerosols in Medicine; 2016:e1-e32.

118. Davies JC, Alton EW, Bush A. Cystic fibrosis. BMJ 2007;335(7632): 1255-1259.

119. Quon BS, Rowe SM. New and emerging targeted therapies for cystic fibrosis. BMJ 2016;352:i859.

120. Knowlton RG, Cohen-Haguenauer O, Van Cong N, Frézal J, Brown VA, Barker D, et al. A polymorphic DNA marker linked to cystic fibrosis is located on chromosome 7. Nature 1985;318(6044):380382.

121. Rommens JM, Iannuzzi MC, Kerem B, Drumm ML, Melmer G, Dean $\mathrm{M}$, et al. Identification of the cystic fibrosis gene: chromosome walking and jumping. Science 1989;245(4922):10591065 .

122. Riordan JR, Rommens JM, Kerem B, Alon N, Rozmahel R, Grzelczak Z, et al. Identification of the cystic fibrosis gene: cloning and characterization of complementary DNA. Science 1989;245(4922): 1066-1073.

123. Matsui H, Grubb BR, Tarran R, Randell SH, Gatzy JT, Davis CW, Boucher RC. Evidence for periciliary liquid layer depletion, not abnormal ion composition, in the pathogenesis of cystic fibrosis airways disease. Cell 1998;95(7):1005-1015.

124. Tang XX, Ostedgaard LS, Hoegger MJ, Moninger TO, Karp PH, McMenimen JD, et al. Acidic $\mathrm{pH}$ increases airway surface liquid viscosity in cystic fibrosis. J Clin Invest 2016;126(3):879-891.

125. Yuan S, Hollinger M, Lachowicz-Scroggins ME, Kerr SC, Dunican EM, Daniel BM, et al. Oxidation increases mucin polymer crosslinks to stiffen airway mucus gels. Sci Transl Med 2015;7(276): $276 \mathrm{ra} 27$.

126. Lyczak JB, Cannon CL, Pier GB. Lung infections associated with cystic fibrosis. Clin Microbiol Rev 2002;15(2):194-222.

127. Konstan MW, Berger M. Current understanding of the inflammatory process in cystic fibrosis: onset and etiology. Pediatr Pulmonol 1997;24(2):137-142; discussion 159-161.

128. Fuchs HJ, Borowitz DS, Christiansen DH, Morris EM, Nash ML, Ramsey BW, et al. Effect of aerosolized recombinant human DNase on exacerbations of respiratory symptoms and on pulmonary function in patients with cystic fibrosis: the Pulmozyme Study Group. N Engl J Med 1994;331(10):637-642.

129. Stephenson AL, Sykes J, Stanojevic S, Quon BS, Marshall BC, Petren K, et al. Survival comparison of patients with cystic fibrosis in Canada and the United States: a population-based cohort study. Ann Intern Med 2017. doi: 10.7326/M16-0858 [Epub ahead of print].

130. De Boeck K, Munck A, Walker S, Faro A, Hiatt P, Gilmartin G, Higgins M. Efficacy and safety of ivacaftor in patients with cystic fibrosis and a non-G551D gating mutation. J Cyst Fibros 2014; 13(6):674-680. 
131. Gill DR, Hyde SC. Delivery of genes into the CF airway. Thorax 2014;69(10):962-964.

132. Griesenbach U, Alton EW. Moving forward: cystic fibrosis gene therapy. Hum Mol Genet 2013;22(R1):R52-R58.

133. Davies LA, Nunez-Alonso GA, McLachlan G, Hyde SC, Gill DR. Aerosol delivery of DNA/liposomes to the lung for cystic fibrosis gene therapy. Hum Gene Ther Clin Dev 2014;25(2):97-107.

134. Kinsey BM, Densmore CL, Orson FM. Non-viral gene delivery to the lungs. Curr Gene Ther 2005;5(2):181-194.

135. Al-Dosari MS, Gao X. Nonviral gene delivery: principle, limitations, and recent progress. AAPS J 2009;11(4):671-681.

136. Alton EW, Boyd AC, Cheng SH, Davies JC, Davies LA, Dayan A, et al. Toxicology study assessing efficacy and safety of repeated administration of lipid/DNA complexes to mouse lung. Gene Ther 2014;21(1):89-95.

137. Alton EW, Armstrong DK, Ashby D, Bayfield KJ, Bilton D, Bloomfield EV, et al. Repeated nebulization of non-viral CFTR gene therapy in patients with cystic fibrosis: a randomized, double-blind, placebo-controlled, phase $2 b$ trial. Lancet Respir Med 2015;3(9): 684-691.

138. Cole P. The damaging role of bacteria in chronic lung infection. J Antimicrob Chemother 1997;40(Suppl A):5-10.

139. Weycker D, Edlesberg J, Oster G, Tino G. Prevalence and economic burden of bronchiectasis. Clin Pulm Med 2005;12(4):205209.

140. Finch S, McDonnell MJ, Abo-Leyah H, Aliberti S, Chalmers JD. A comprehensive analysis of the impact of Pseudomonas aeruginosa colonization on prognosis in adult bronchiectasis. Ann Am Thorac Soc 2015;12(11):1602-1611.

141. Wilson R, Aksamit T, Aliberti S, De Soyza A, Elborn JS, Goeminne $\mathrm{P}$, et al. Challenges in managing Pseudomonas aeruginosa in non-cystic fibrosis bronchiectasis. Respir Med 2016; 117:179-189.

142. Onen ZP, Gulbay BE, Sen E, Yildiz OA, Saryal S, Acican T, Karabiyikoglu G. Analysis of the factors related to mortality in patients with bronchiectasis. Respir Med 2007;101(7):1390-1397.

143. Wilson R, Welte T, Polverino E, De Soyza A, Greville H, O'Donnell A, et al. Ciprofloxacin dry powder for inhalation in non-cystic fibrosis bronchiectasis: a phase II randomised study. Eur Respir J 2013;41(5):1107-1115.

144. McShane PJ, Naureckas ET, Tino G, Strek ME. Non-cystic fibrosis bronchiectasis. Am J Respir Crit Care Med 2013;188(6):647-656.

145. Tunney MM, Einarsson GG, Wei L, Drain M, Klem ER, Cardwell $\mathrm{C}$, et al. Lung microbiota and bacterial abundance in patients with bronchiectasis when clinically stable and during exacerbation. Am J Respir Crit Care Med 2013;187(10):1118-1126.

146. Mirsaeidi M, Hadid W, Ericsoussi B, Rodgers D, Sadikot RT. Non-tuberculous mycobacterial disease is common in patients with noncystic fibrosis bronchiectasis. Int J Infect Dis 2013;17(11):e1000e1004.

147. Chalmers JD, Hill AT. Mechanisms of immune dysfunction and bacterial persistence in non-cystic fibrosis bronchiectasis. Mol Immunol 2013;55(1):27-34.

148. McDonnell MJ, Jary HR, Perry A, MacFarlane JG, Hester KLM, Small T, et al. Non cystic fibrosis bronchiectasis: a longitudinal retrospective observational cohort study of Pseudomonas persistence and resistance. Respir Med 2015;109(6):716-726.

149. Angrill J, Agustí C, De Celis R, Filella X, Rañó A, Elena M, et al. Bronchial inflammation and colonization in patients with clinically stable bronchiectasis. Am J Respir Crit Care Med 2001;164(9): 1628-1632.

150. Chalmers JD, Smith MP, McHugh BJ, Doherty C, Govan JR, Hill AT. Short- and long-term antibiotic treatment reduces airway and systemic inflammation in non-cystic fibrosis bronchiectasis. Am J Respir Crit Care Med 2012;186(7):657-665.

151. Rubin BK, Williams RW. Aerosolized antibiotics for non-cystic fibrosis bronchiectasis. Respiration 2014;88(3):177-184.

152. Bilton D, Henig N, Morrissey B, Gotfried M. Addition of inhaled tobramycin to ciprofloxacin for acute exacerbations of Pseudomonas aeruginosa infection in adult bronchiectasis. Chest 2006;130(5): 1503-1510.

153. Haworth CS, Foweraker JE, Wilkinson P, Kenyon RF, Bilton D. Inhaled colistin in patients with bronchiectasis and chronic Pseudomonas aeruginosa infection. Am J Respir Crit Care Med 2014; 189(8):975-982.

154. Barker AF, O’Donnell AE, Flume P, Thompson PJ, Ruzi JD, de Gracia $\mathbf{J}$, et al. Aztreonam for inhalation solution in patients with non-cystic fibrosis bronchiectasis (AIR-BX1 and AIR-BX2): two randomised double-blind, placebo-controlled phase 3 trials. Lancet Respir Med 2014;2(9):738-749.

155. Stass H, Weimann B, Nagelschmitz J, Rolinck-Werninghaus C, Staab D. Tolerability and pharmacokinetic properties of ciprofloxacin dry powder for inhalation in patients with cystic fibrosis: a phase I, randomized, dose-escalation study. Clin Ther 2013;35(10): 1571-1581.

156. Stass H, Delesen H, Nagelschmitz J, Staab D. Safety and pharmacokinetics of ciprofloxacin dry powder for inhalation in cystic fibrosis: a phase I, randomized, single-dose, dose escalation study. J Aerosol Med Pulm Drug Deliv 2015;28(2):106-115.

157. DeSoyza A, Aksamit T, Bandel T-J, Criollo M, Elborn S, Krahn U, et al. Efficacy and tolerability of ciprofloxacin dry powder for inhalation (Ciprofloxacin DPI) in bronchiectasis (non-CF etiology): results from the phase III RESPIRE 1 study. Chest 2016;150(4_S): 1315A. doi: 10.1016/j.chest.2016.08.1446.

158. Aradigm Corp. Aradigm announces top-line results from two phase 3 studies evaluating Pulmaquin for the chronic treatment of noncystic fibrosis bronchiectasis patients with lung infections with Pseudomonas aeruginosa. Press release December 1, 2016. http:// investor.aradigm.com/releaseDetail.cfm?ReleaseID $=1001671$. Accessed April 14, 2017.

159. Diaz KT, Skaria S, Harris K, Solomita M, Lau S, Bauer K, et al. Delivery and safety of inhaled interferon- $\gamma$ in idiopathic pulmonary fibrosis. J Aerosol Med Pulm Drug Deliv 2012;25(2):7987.

160. Nikander K, Prince I, Coughlin S, Warren S, Taylor G. Mode of breathing-tidal or slow and deep-through the I-neb adaptive aerosol delivery (AAD) system affects lung deposition of (99m)TcDTPA. J Aerosol Med Pulm Drug Deliv 2010;23(Suppl 1):S37S43.

161. Fusiak T, Smaldone GC, Condos R. Pulmonary fibrosis treated with inhaled interferon- $\gamma($ IFN- $\gamma$ ). J Aerosol Med Pulm Drug Deliv 2015; 28(5):406-410.

162. Grana R, Benowitz N, Glantz SA. E-cigarettes: a scientific review. Circulation 2014;129(19):1972-1986.

163. Schoenborn CA, Gindi RM. Electronic cigarette use among adults: United States, 2014. NCHS Data Brief 2015;(217):1-8

164. Brook RD, Rajagopalan S, Pope CA 3rd, Brook JR, Bhatnagar A, Diez-Roux AV, et al. Particulate matter air pollution and cardiovascular disease: an update to the scientific statement from the American Heart Association Circulation 2010;121(21):23312378.

165. Kalkhoran S, Glantz SA. Modeling the health effects of expanding e-cigarette sales in the United States and United Kingdom: a Monte Carlo analysis. JAMA Intern Med 2015;175(10):16711680.

166. FDA Center for Tobacco Products. Overview of the Family Smoking Prevention and Tobacco Control Act. June 2009. http:// 


\section{INHALED DRUG THERAPY}

www.fda.gov/downloads/TobaccoProducts/GuidanceCompliance RegulatoryInformation/UCM336940.pdf. Accessed April 14, 2017.

167. Benzaldehyde [MAK Value Documentation, 2002]. The MAK Collection for Occupational Health and Safety. Weinheim, Germany: Wiley-VCH Verlag GmbH \& Co. KGaA; 2012:14-36.

168. Barrington-Trimis JL, Samet JM, McConnell R. Flavorings in electronic cigarettes: an unrecognized respiratory health hazard? JAMA 2014;312(23):2493-2494.

169. Kosmider L, Sobczak A, Prokopowicz A, Kurek J, Zaciera M, Knysak J, et al. Cherry-flavoured electronic cigarettes expose users to the inhalation irritant, benzaldehyde. Thorax 2016;71(4):376377.
170. United States Environmental Protection Agency. Compendium of methods for the determination of toxic organic compounds in ambient air. Method TO-11A. Cincinnati, Ohio: Environmental Protection Agency, 1999. http://www.epa.gov/ttnamti1/files/ambient/ airtox/to-11ar.pdf. Accessed April 14, 2017.

171. Pang X, Lewis AC. Carbonyl compounds in gas and particle phases of mainstream cigarette smoke. Sci Total Environ 2011;409(23): 5000-5009.

172. Shahab L, Goniewicz M, Blount B, Brown J, McNeill A, Alwis $\mathrm{KU}$, et al. Nicotine, carcinogen, and toxin exposure in long-term e-cigarette and nicotine replacement therapy users. Ann Intern Med 2017. doi: 10.7326/M16-1107 [EPub ahead of print]. 